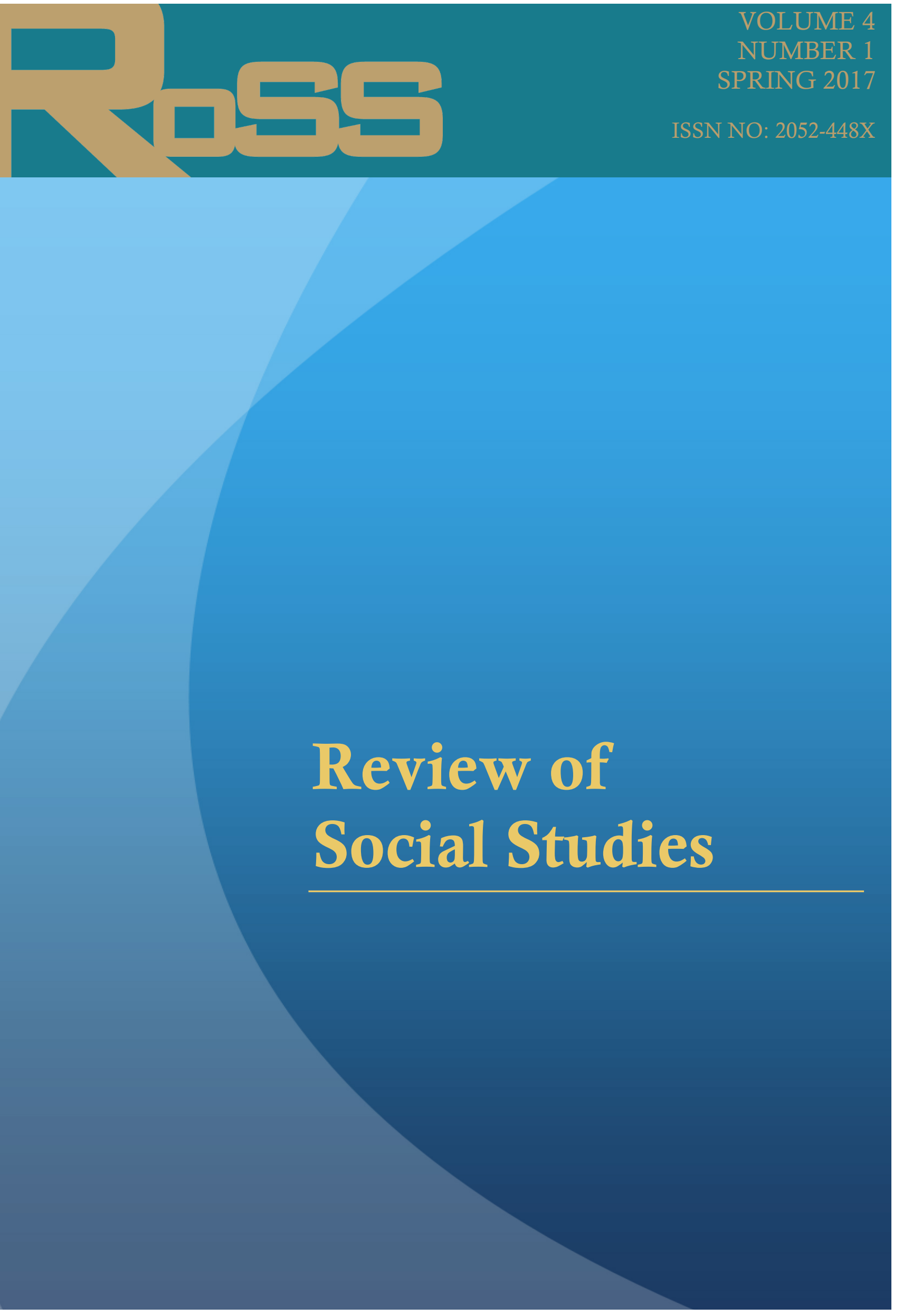


Review of Social Studies (RoSS) is an interdisciplinary journal. The principal purpose of the journal is to publish lucid and well-documented peer-reviewed articles that discuss significant social, legal and political issues in an international context. Wideranging in scope, the journal welcomes scholarly essays that cut across disciplinary boundaries, and reflect original and critical thinking on the latest developments in the theory and practice of social sciences. These areas include, but are not limited to, the fields of anthropology, sociology, law, politics, history, international relations, culture, gender, migration, diaspora and ethnic studies.

RoSS publishes two issues a year (Spring and Autumn). One of these may be a special issue composed of selected conference papers. RoSS has also a book review section which reflects academic and intellectual diversity in recent social science publications.

Editorial Office address: 73 Watling Street London EC4M 9BJ

Tel.: +44 (0) 2076070878

Website: http://www.rossjournal.co.uk

ISSN No. 2052-448X (Online)

Correspondence concerning editorial content and potential submissions should be addressed to the editor: editor@rossjournal.co.uk

Disclaimer: Each author has full responsibility for their work. The publisher, Review of Social Studies (RoSS) and the Editors of this journal cannot be held responsible for errors or any consequences arising from the use of information contained in this journal. The views and opinions expressed do not necessarily reflect those of the Publisher, RoSS or the Editors; nor do they constitute an endorsement by the Publisher, RoSS or Editors of the views or any products mentioned.

Apart from fair dealing for the purposes of research and private study, or criticism or review, and only as permitted under the Copyright Designs and Patents Act 1988, this publication may be reproduced, stored or transmitted in any form or by any means, only with the prior permission in writing of the Publishers.

\section{Editorial Board}

Editor in chief:

Ufuk Ucar, LCSS, UK

Associate Editors:

Dr. Leigh Graham, Columbia Uni., USA

Dr. Federica Sona, SOAS, UK

Ian Kalman, McGill University, Canada

Tania Khojasteh, SOAS, UK

Samantha North, Independent Researcher

Seref Kavak, Keele University, UK

Kubra Uygur, Birmingham Uni., UK

\section{Academic Advisory Board}

Prof. Werner Menski, SOAS, UK

Prof. Ralh Grillio, University of Sussex, UK

Prof. Yasemin G. Inceoglu, Galatasaray

University, Turkey

Associate Prof. Vildan Iyigungor, Marmara

University, Turkey

Dr. Katrin Seidel, Max Planck Institute for

Social Anthropology (MPI), Germany

Dr. Aisling Lyon, Independent Researcher, UK

Dr. Edyta Roszko, Durham University, UK

Dr. Julie Billaud, Max Planck Institute for Social Anthropology (MPI), Germany 
VOLUME 4

NUMBER 1

SPRING 2017

\section{REVIEW}

OF

\section{SOCIAL STUDIES}

Published in London, United Kingdom 


\section{CONTENTS}

\section{ARTICLES}

Changing School - Changing Self. Ethnic Minority Girls' Active Struggles for Educational Success

Anika Liversage

Nation Divided: Building Identities through Bosnian History Adnan Pečković

Empowering Others: Motives and Strategies Successful Ghanaian Women Adopt

Doris Abena Akyere Boateng and Kwaku Osei-Hwedie

John Fowles's The French Lieutenant's Woman as a New-Historical Novel

Ela İpek Gündüz

The Ottoman Empire as Friend and Foe: Perceptions of Ottoman Rule in Serbia and Bosnia and Thereupon Based Nationalisms Srđan M. Jovanović

BOOK REVIEW

Virtue in Business (by Edwin M. Hartman)

Selcuk Uygur 


\title{
Changing School - Changing Self. Ethnic Minority Girls' Active Struggles for Educational Success
}

\author{
ANIKA LIVERSAGE \\ The Danish National Centre for Social Research, Denmark
}

\begin{abstract}
As education is of great importance for individual success, it perpetuates inequalities when ethnic minorities are educated less than majority populations. Based on life stories with ethnic minority women who have done well in the Danish educational system, this article offers a detailed analysis of a critical time period in early adolescence where such young women's dreams of upward social mobility were threatened. In the 'contact zone' of their local school classes, the proximity to ethnic majority pupils' experiments with alcohol and cigarettes challenged the educational aspirations of the ethnic minority teenage girls. The article conceptualises this challenging time as a 'vital conjuncture' - a critical life period in which both different futures and different identities are at stake - and shows how a school change could alleviate personal pressures, and avert the impending danger of school drop-out. This analytical approach demonstrates both how intersecting identities tied to ethnicity, gender, and class may operate in different ways, but with similar consequences of threatening educational success, and points to the scope of agency which ethnic minority teenage girls may exert as they struggle to shape their futures, but not in circumstances of their own choosing.
\end{abstract}

\section{Introduction}

Education is generally considered of great importance for individual success in societies worldwide. Hence, it perpetuates inequalities when ethnic minorities fare less well in education than majority populations (Christensen, Egelund, Fredslund and Jensen 2014, Heath and Brinbaum 2007, OECD 2006; Source removed).

Different explanations for this phenomenon coexist, and they include the lower class positions of ethnic minority families; differences in immigrants' cultural and linguistic backgrounds from those of the majority, and the persistence of discriminatory practices in national educational systems (Archer and Francis 2007, Collier and Thomas 2002, Ferguson 2001, Tenenbaum and Ruck 2007).

Faring well in education is thus often challenging for immigrant and refugee children. Drawing on life story narratives with ethnic minorities, this article investigates both experiences of and responses to such challenges. Using interview material with 25 ethnic minority women, all of whom completed their educations in Denmark, the article focuses primarily on the narratives of three women, explicating how they struggled to overcome inequalities of class, gender and ethnicity at a crucial point in their educations and lives - in their early adolescence, around age 14 . 
The article suggests the concept of 'vital conjuncture' - a term coined by the demographer Jennifer Johnson-Hanks (2002) - as well suited for analysing these narratives. The concept of a vital conjuncture is:

...a temporary configuration of possible change, a duration of uncertainty and potential [...]. Vital conjunctures are particularly critical durations, where more than usual is in play, where the futures at stake are significant (Johnson-Hanks 2002: 871).

The concept can facilitate a better understanding of both how perceived threats arising from specific intersections of gender, class and ethnicity may endanger young minority women's aspirations for achieving upward social mobility and also how such women may be able to resist and change the difficult situations in which they find themselves.

The aicle, first, outlines the context of the study, namely the Danish educational system, with a focus on the roles that identities tied to ethnicity, class and gender are known to have. Second, it unpacks the concept of vital conjuncture, before, third, discussing the methodological approach of life story interviews. Fourth, the analysis draws on the selected narratives of young women facing difficulties in education but overcoming these challenges through changing schools. The article ends with conclusions.

\section{The context of the study - ethnicity, class and gender in the Danish educational system}

The article's study is set in Denmark, a Scandinavian welfare state with only 5.5 million inhabitants. It is a small country by European standards, and its history of larger-scale visible immigration is relatively recent, dating back only to the 1960s (Koefoed and Simonsen 2010).

Today, according to Statistics Denmark, $10.1 \%$ of the population are immigrants or descendants of immigrants. The share of immigrants of nonWestern origin, including their descendants, stands at $6.7 \%$ of the total population (Statistics Denmark 2010). Thus while Denmark's share of ethnic minorities is rather low when compared to countries such as the UK or neighbouring Sweden, one in ten pupils in the Danish school system nevertheless do not have Danish as their mother tongue as they have nonWestern family backgrounds (Nusche, Wurzburg, and Naughton 2010).

Possibly due to the historically recent changes in the otherwise quite homogeneous Danish population, the majority/minority dividing line appears to be attributed considerable importance in Danish schools, even though educational institutions often seek to downplay this division (GitzJohansen 2006). The importance of this division may arise from 'equality' being considered a central cultural value in Scandinavia, with the added understanding that being 'equal' implies being 'alike' (Gullestad 1992). As 
visibly different ethnic minorities stand out from the majority, many majority Danes view such 'foreigners' as challenging national similarity and unsettling national cohesion (Hervik 2004). It is therefore no wonder that in a Scandinavian context, ethnic minority pupils often feel negatively 'different' in the school context (Runfors 2003), where they also may often face lower expectations from teachers (Gilliam 2006; Tenenbaum and Ruck 2007) and have to work extra hard if they wish to gain acceptance (Hällgreen 2005).

Recent institutional ethnographies demonstrate the salience of this majority/minority dividing line. In the 'contact zone' (Phoenix 2009; Pratt 1991) of the Danish 'Folkeskole' - compulsory education, lasting for ten years, and ending when students are around the age of 15. Research shows that 'Danish' (i.e. white majority) children are generally those whom the teachers here single out as 'good pupils', while 'foreign' children - and especially boys - are often perceived as problematic (Gilliam 2006). As a consequence, similar behaviour from pupils may elicit different teacher responses, depending on the pupil's ethnic background (K. Andersen 2005; Gilliam 2006). Minority pupils may also face challenges relative to the tuition's taking place in a language that is not their mother tongue (Collier and Thomas 2002) and due to the value attributed to nation-specific knowledge, to which ethnic minority children have less access (Gitz-Johansen 2006; Pastoor 2009).

As well demonstrated by intersectionality studies (Gross, Gottburgsen and Phoenix 2016; Valentine 2007), ethnicity often centrally intersects with class. As Denmark historically has had limited skilled labour migration, a large share of the immigrants and refugees entering the country since the 1960s have had low levels of educational qualifications (Tranæs and Zimmermann 2004). Adding to this problem, skilled individuals arriving, for example as refugees or marriage migrants, often have difficulties putting their qualifications to use in the Danish labour market (Nielsen, C 2011). Thus from a class perspective ethnic minorities in Denmark are overrepresented in lower class levels. Today, as a 'second generation' is increasingly moving through the Danish educational system, the perpetuation of these class differences is central to understanding why ethnic minority youth fare less well in education than their majority peers (Jakobsen 2015).

However, whilst such lower class positions of ethnic minority families generally delimit the resources available for children's educational achievements, this low class position may conversely feed educational aspirations. Furthermore, in Denmark - in contrast to many of the ethnic minority families' countries of origin - education is not only readily available and free, but the state also offers all students at higher levels a subsistence grant, thereby supporting studying for all, regardless of family background. Hence, many ethnic minority families see education as an option for bettering 
the class position of the next generation, and attribute great importance to their children's studying (Andersen, J 2008). This attitude has been termed an 'immigrant drive' towards educating (Lauglo 1996). As documented elsewhere in Scandinavia (Sletten 2001; Støren and Helland 2009), high educational aspirations are similarly found among immigrants in other national contexts (Perreira, Harris and Lee 2006; Salikutluk 2016).

Ethnicity and class intersect with gender in various ways relevant for educational success. A first general observation is that girls - regardless of ethnic background - often fare better in education than boys (Bakken et al. 2008). This gendered difference is largely due to the often limited educational achievement of lower-class boys, who may respond with opposition when faced with school demands that they have limited resources for meeting (Jackson 2003; Willis 1977). Of particular importance for the present study is how broader gendered expectations may affect ethnic minority women at school. Research shows that female behaviour is often considered a boundary marker of great importance for ethnic minority groups (Mooney 2006; YuvalDavis 1997). Hence, for example, ethnic minority girls from Muslim backgrounds may face gendered expectations - e.g. abstaining from drinking alcohol and not dating - that differ considerably from the expectations facing girls from the majority (Prieur 2004).

\section{Conceptual approach}

The variable importance of identities linked to gender, class and ethnicity take on importance in human interaction. Symbolic interactionism tells us that all identities always have an internal and an external dimension: the internally oriented identification of self and the externally oriented categorisation of others. 'Who one is' is thus never fixed once and for all but is always open for negotiation and central to the interplay between the individual and the collective (Jenkins 2004). As we can all identify with, as well as be categorised by, different systems of categorisation, we 'are' not (essentially) one thing or another. Rather, different systems of categorisation intersect in various ways and intermesh with one another in specific historical situations.

Thus gender and ethnicity may centrally structure experiences in the educational system. So may class, but time spent in education may also in itself affect class: completing of educations at higher levels facilitates entry into the higher echelons of a society, and education is thus a primary route to class mobility.

Such educational journeys towards achieving higher positions in social space must be "...paid for by labour, by effort and especially by time" (Bourdieu 1992: 232). While the 25 interviewees in this study had all successfully 
completed this journey, many had felt challenged at one or more points along the way. This article suggests that such a time of challenge can usefully be conceptualised as a 'vital conjuncture':

...a socially structured zone of possibility that emerges around specific periods of transformation in a life or lives. It is a temporary configuration of possible change, a duration of uncertainty and potential... [Here] action is conjoined to a particular, temporary manifestation of social structure, [making vital conjunctures] particularly critical durations when more than usual is in play, when the futures at stake are significant (Johnson-Hanks 2002: 871).

Johnson-Hanks takes the term 'conjuncture' from Bourdieu (1977), who uses it to express the conditions that manifest social structure and that thus serve as the effective context for social action. While 'vital' comes from demography's 'vital events' of important status passages such as birth, marriage and death (Johnson-Hanks 2002: 872), Johnson-Hanks states that the concept can also encompass other important status passages such as graduation or dropping out of education. Proposed as an alternative to the life stages approach in ethnography, a vital conjuncture as a unit of social analysis is "...based in aspiration, rather than event" (865), and proposes a way of working between the individual and the social in a world, where life courses vary considerably - an observation that diminishes the relevance of working with a pre-determined set of consecutive life stages.

Having a dual focus on societal institutions and individual aspirations, the concept of vital conjuncture is well suited for grasping the experiential dimension of social processes, which on larger scales may coalesce into recurring systematicness (Johnson-Hanks 2002: 872). In the present case, the concept may thus add to our understanding both of the generally lower levels of educational attainment among ethnic minority youth and of the ways in which achieving educational success may be closely linked to individuals' hopes and aspirations, upon which they seek to act.

As a last step before applying this concept to the analysis of ethnic minority women being educated in Denmark, I describe the method I used and the way in which it ties in with the conceptual approach.

\section{Methodological approach}

Half a century ago, C. Wright Mills wrote his renowned book The Sociological Imagination, in which he argued that sociology should concern itself with the interrelation of individual and society:

The facts of contemporary history are also facts about the success and the failure of individual men and women. [...] Neither the life of an individual nor the history of a society can be understood without understanding both (Mills 1959: 1). 
Today, life story interviews remain a method well suited for the endeavour of interrelating individuals and broader societal contexts (Walker 2005). As French sociologist Daniel Bertaux argues, such interviews contain detailed information on individuals' 'situated courses of action' through time and space. Carried out with a group of individuals who have shared similar life circumstances, a body of life story interviews can thus add to our understanding not only of individual life experiences but also of broader social processes (Bertaux 2003).

A life as told, however, is very different from a life as lived. With the linguistic turn calling attention to the constructed nature of texts, we cannot take life stories as unproblematic windows into people's past lives. A life story is a retrospective narrative construction, made from a given present-day viewpoint and in a specific interactional interview situation with a researcher-cum-interviewer (Holstein and Gubrium 2000).

A useful tool for attending to the constructed nature of a life story is to distinguish between the 'narrator' (the individual telling the life story) and the 'protagonist' (the narrator's former self, as constructed in the life story; Goffman 1986: 520). For example whilst the narrator may be a 30-year-old woman with a completed education, the protagonist in the text of the life story will be her former self constructed at various ages, growing and maturing, and at times facing crossroads she must choose between. The protagonist of the narrated life story will at one point in the interview reach the space and time of the present-day narrator, who is telling the life story, and this present-day ending point is of great significance for the construction of the entire narrative (Holstein and Gubrium 2000). Throughout, it is the present-day narrator who attributes importance to certain events and not to others, as she explicates the development of the protagonist (her former self) over time. Consequently, an analytical focus on passages that are narrated in great detail can be a methodological tool for investigating the times of challenges and the turning points to which the interviewees themselves attribute importance (Source removed).

\section{The interview material}

This study is based upon a body of 25 interviews. All the interviewees were women, all were of non-Western ethnic minority origin, and all had completed a tertiary education in Denmark (lasting between three and a half and five years), with around half the interviewees having completed master degrees at Danish universities. The women differed in a number of ways, e.g. age, country and class, as well as whether they had been born in Denmark or not. The women were recruited through a number of different channels, including personal networks, educational institutions and places of work. 
As to interview approach, the women were told about the study's interest in their educational experiences, and then asked to freely tell their story 'from the beginning'. As the women started speaking, interruptions were kept to a minimum to allow the narratives to unfold without undue interference (Source removed). Instead of posing all emerging questions immediately, the interviewers jotted down topics of interest whilst listening and brought up those issues in later stages of the interviews. All interviews were taped and subsequently transcribed. Experiences of meeting challenges in achieving their educational goals, due to intersecting inequalities of class, gender and ethnicity, occurred in varying forms in most of the interviews. This analysis focuses on the narratives of three women, particularly on their experiences in the last years of 'Folkeskole', when they were around 14 years old. The choice of in-depth analysis of a selected few interviews was made to give space to the uniqueness of single lives and to avoid fragmenting their individual life stories (Gullestad 1996).

\section{Majority/minority divisions at school - Sayyidah's case}

The first case it that of Sayyidah ${ }^{1}$. Born in Denmark, her parents had come to Denmark as labour migrants from Pakistan in the early 1970s. Of her last years in 'Folkeskole', Sayyidah says:

\footnotetext{
'My time in 'Folkeskolen' was fine. I lived in Vesterbro [central Copenhagen district with many immigrants] until I was 12 years old. I felt at home there. But then we moved to Valby [less central Copenhagen district, with fewer immigrants.]. There were not so many foreigners there - there were only two in my class. It wasn't great at all. All the time you felt outside in some way, I don't think they were used to foreigners at that school. But then I entered high school, and there were a lot of foreigners there again - it certainly improved'.
}

This statement evokes the theme of this article: First, the time in question is the last period of mandatory schooling, which coincides with the first years of adolescence, around the age of 14 . Second, a central issue is how the shares of 'Danes' vs. 'foreigners' in a given school affect the person's well-being. Third, the theme is how changing school at this time may alter the person's situation. Sayyidah experiences two such school changes, one when her parents moved the family to a new school district and the second when she entered high school after completing 'Folkeskole'. Sayyidah's statement clearly shows that the share of other 'foreigners' in the 'contact zone' of her school environment was central for whether she felt included or excluded during these years. While Sayyidah does not posit the challenges of feeling 'outside' at school as having endangered her educational ambitions, the next sections will show that for other women, lacking group peers at school during

\footnotetext{
${ }^{1}$ All names are pseudonyms. Details of e.g. geographical places may have been changed to protect anonymity.
} 
the years of early adolescence can indeed be experienced as an imminent threat to one's educational aspirations.

\section{Introducing Liyana and Mahsa}

The remainder of the article focuses on the narratives of Liyana and Mahsa, who both were the children of refugees and who, with their parents, arrived in Denmark as young children. The article contrasts and compares their narratives, focusing on the interplay between individual well-being and identity constructions in the school context, issues which affects students' abilities of achieving academic success (Ulriksen, Murning and Ebbensgaard 2009).

Liyana's family came as Palestinian refugees from Lebanon. Whilst her parents were both educated, in Denmark only her mother managed to find employment. Liyana was the oldest child, having two younger sisters, and thus she was the first child that her parents had to raise in Denmark.

Mahsa's family came as refugees from Iran, where they had been politically active. Both parents were educated, and after re-educating in Denmark, both managed to find qualified employment, although at lower levels than in their country of origin. Nonetheless, they did not find settling in Denmark easy, and they were divorced before Mahsa reached school age. Such household break-ups occur very frequently in Iranian refugee families, in part due to the stresses of flight and settlement in a new context, which seem to affect men and women in different measures (Darvishpour 1999). Mahsa and her sister came to live with their mother, who occasionally suffered from depression. The older sister did poorly at school and had considerable personal problems.

\section{Point of departure - school choice and share of pupils with ethnic minority background}

Due to the two families' limited incomes, both Liyana and Mahsa grew up in residential areas of rented flats, occupied predominantly by ethnic minorities. Renting is in line with the general situation in Denmark, where ethnic minorities are underrepresented in the owner-occupied housing of the majority Danish middle class (Statistics Denmark 2010). Housing segregation clearly affects the composition of pupils in local schools, giving some public schools in segregated residential areas very large shares of ethnic minority pupils. Indeed, in Denmark around one in five ethnic minority children attends schools in which more than $70 \%$ of the pupils are ethnic minorities like themselves (OECD 2006, 74). These schools are in Danish colloquially termed 'black' schools, as compared to majority-dominated 'white' schools, and research has linked such large shares of ethnic minority pupils to lower levels of academic achievement (Jensen and Rasmussen 2008; Szulkin and Jonsson 2007). 
Apparently keen to facilitate the academic achievements of their daughters, the parents of both Liyana and Mahsa opted for their daughters to enter schools at some distance from the neighbourhood school, dominated by the Danish majority. As both sets of parents were well educated, their awareness of and resources underlying this choice can be interpreted as one of the ways in which parents seek to transmit class across generations. Thus the two interviewees tell the following stories:

We lived in [residential area] where there were many children with ethnic minority backgrounds. So, even though it was far away, my parents sent me to another school, in order for me to learn Danish (Liyana).

I lived in [residential area with many ethnic minorities] and the school I went to was in a very different area, in such a hippie district, where all those from the detached houses and the villas went to school (Mahsa).

Liyana here states that the linguistic differences linked to the share of ethnic minority pupils was central for her parents' school choice on her behalf: The choice of the more distant school was made for her to learn (better) Danish, considered central for her future prospects in Denmark. Mahsa instead foregrounds the class difference associated with the choice of a 'white' school, saying that her school peers were the children of 'hippies', living in 'detached houses' and 'villas'. In a few words, Mahsa thus conjures up a central-leftleaning majority Danish middle class, affluent enough to be home owners. This affluence differed greatly from the economic situation in Mahsa's deprived ethnic minority neighbourhood, and the troubled family life that framed her own childhood.

While both girls began their schooling in rather distant schools, they also both experienced feeling 'different' in ways that they did not find easy to handle. Like Sayyidah, Mahsa also expressed feeling that she did not 'fit in' at her school:

I was in a fine class and I had friends and I had been home with my classmates and all that. But I never really felt that I was really within, truly a part of the class. They were sweet enough, but I just kind of did not fit in. I was an outsider (Mahsa).

Mahsa continues that in the $7^{\text {th }}$ grade (when she was 14), her time at school became so problematic as to endanger her future possibilities for education. Liyana had similar fears at this age. The challenges that these two narrators experienced at this time in their lives is the topic of the next section.

\section{Adolescent changes and gendered challenges - Liyana's case}

With the onset of adolescence, pupil behaviour generally changes markedly in the Danish 'Folkeskole'. Experiments with practices associated with youth life commonly begins in the $7^{\text {th }}$ grade, and whilst both drinking and smoking may often be prohibited by parents and school staff, trying out such practices 
is often considered part of 'growing up' in Denmark. Thus more than $80 \%$ of Danish youth have been drunk by the age of 15 (Rheinländer 2007), young Danes are some of the heaviest drinkers in Europe (Hibell et al. 2009; Demant and Krarup 2013), and much interaction in Danish schools revolves around alcohol, parties and dating (Demant and Østergaard 2007; Staunæs 2003)22. Liyana explicitly addressed these age-related changes in the practices of her majority Danish classmates:

At one time it just became tough for me, because Danish children, in the 7th grade, they start getting new habits. Funnily enough it is cigarettes and alcohol and such. And I wasn't allowed to do that. It was both that I did not want to do anything wrong towards my parents, but it was also that it felt like the right thing [not to drink and smoke] because I knew it was outside my culture and my norms. So it was just really difficult (Liyana).

The challenges Liyana refers to here arise from intersections of ethnicity and gender, and the associated discrepancy between expectations at school and at home: in her class she faced peer pressures of participating in the 'new habits' of the 'Danes' - but doing so was at odds with the culture and norms of her family background, a cross-pressure that is a recurrent theme in studies of young ethnic minority females in education (Ajrouch 2004; Espiritu 2001). Adhering to these norms was especially crucial for Liyana, as her father was ambivalent about her being educated in the first place:

My father was not quite sure of what he wanted for us girls. He heard his family [in the Middle East] saying: "Girls, they should not be educated. They are bound to be homemakers for their husbands anyway". So he wasn't quite sure of how to handle us. Whether we should be the capable Muslim girls [in education] or whether we should be in the home - cooking and cleaning. He was frustrated, when he saw that his friend's children were good at cleaning. One girl wearing a [head]scarf and all. [My father] was really torn, and it was tough on him, I think. He came from a background where he had been educated, but all of his family were uneducated (Liyana).

As both minor and a female, Liyana's position was one of dependency. If her father withdrew his support of her studying, she could do little to achieve her educational goals. This type of conflict between educational aspirations and traditional gender role expectations, challenging ethnic minority girls' educational participation, is also documented in other settings (Ahmad 2001).

Class is also present in Liyana's narrative about her father's ambivalence towards her education. She points out that whilst her father was educated (albeit unemployed in Denmark), all of his family was 'uneducated'. Liyana

\footnotetext{
${ }^{2}$ Another central element in the youth culture is experimenting with intimate relationships. Thus, on average, a young Danish woman has her sexual debut shortly before turning 16 (L. Nielsen 2007).
} 
offers this lack of education in her father's family as an explanation for why he did not wholeheartedly support her studies.

When Liyana explains why staying in education was so important to her, she states that doing so was not only due to considerations about her future class position. Education would also centrally intersect with gender relations, and thus have a direct bearing on her intimate life and the scope of selfdeterminacy, that she could achieve in this life domain. As she said in the interview:

Already in the $7^{\text {th }}, 8^{\text {th }}$ grade, I wanted more and more freedom. There was this thing that you, as a girl, you should be 'below' the man. And I didn't want that. So I felt that the only way I could come to say to a man: "You know what? You are not right. What I say is right, and I know that" - doing so would only be possible if I were educated (Liyana).

As other studies have shown (e.g. Kragh 2010), succeeding in education may indeed equip young ethnic minority women with resources that enable them to transform and reduce patriarchal control in their personal lives, a dynamic that may in itself increase the educational aspirations of such young women.

\section{Adolescent changes and classed challenges - Mahsa's case}

Mahsa also encountered difficulties in the $7^{\text {th }}$ grade, but compared to Liyana, her challenges were structured in rather different ways. She relates the following about that time:

I was a bit of a rebel and was friends with the punk girl of the class. Then, in the $7^{\text {th }}$ grade I started skipping school like crazy - went out and smoked cigarettes instead of attending classes (Mahsa).

Likewise experiencing the changing habits of her majority Danish classmates in the last years of 'Folkeskolen', Mahsa did not distance herself (as Liyana did) from the majority practices of drinking and smoking. Instead, Mahsa herself partially changed her practices in this direction.

While smoking can damage one's health, Mahsa's skipping school at the time was a more serious threat to her future educational aspirations. Her behaviour at this life stage can be labelled 'deviant', presumably springing largely from her problems in the family domain (i.e. her entire family remained marked by the traumatic experiences of having had to flee their country). Mahsa continues:

'... I really just felt terrible. I probably had a depression or something. I had all that pain inside of me, due to what I had experiences, but my classmates had no idea about what the heck I was talking about'. 
Furthermore, at home, Mahsa had to 'just take care of [her]self' due to her life with an absent father, a mother with psychological problems, and a sister whose hardships overshadowed any of her own. Mahsa's challenges were thus not linked to the same type of intersection between of gender and ethnicity, with which Liyana struggled, but rather to her specific refugee background and the upheavals of persecution and flight. Indeed, Mahsa's parents were well-educated leftist refugees, and subscribed to much more liberal norms for young female conduct than Liyana's father did. It was primarily Mahsa's deeply troubled family life that undermined her wellbeing, including in school. This observation underscores the importance of not expecting all ethnic minority girls from Muslim countries to be facing, for example challenges of patriarchal control (Keddie 2011).

\section{Dangerous times and vital conjunctures}

Regardless of the specificities of the challenges they faced, both Liyana and Mahsa relate that they, around the age of 14, feared that the troubles with which they were grappling could endanger their educational futures. Hence, I posit that these times of their lives can be considered vital conjunctures, as they were precisely "particularly critical durations, where more than usual is in play, where the futures at stake are significant" (Johnson-Hanks 2002: 871). Such conjunctures draw their significance from the fact that the contested futures not only concern what will happen in the time ahead, but also have major implications for "...the future person, the range of identities that could possibly be claimed" (872). In Liyana's and Mahsa's cases, they feared that the strains they were facing would throw them off the educational path - and if they could not succeed in school, they would not be able to become the educated selves they aspired to be.

Vital conjunctures have different imagined futures as their horizons, and "the analysis of vital conjunctures rests on an understanding of what horizons, what futures, are imagined, hoped for, or feared" (Johnson-Hanks 2002: 872). Thus, according to both narratives, although both girls wanted to stay on the path towards becoming well educated, they could also see the path of a school dropout looming ahead of them - a path likely to lead them towards a much less desired future. With research showing that ethnic minority pupils more often than their majority peers either drop out of education or end school without the skills necessary for educating further, the two girls' fears at the time were most likely not exaggerated. Their feeling the pressure of this growing danger to their future aspirations raises the question of what the girls themselves could do to make one future, and not the other, become a reality.

As young individuals, they had few options for affecting the larger structures of class, gender and ethnicity in which they were enmeshed. While changing 
their cultural background, skin colour or family history was of course not an option, one avenue for action lay potentially open: they could seek to change the schools they went to and, by moving to a different spatial location, alter the micro-context of their day-to-day school lives. Both Liyana and Mahsa did so. Both initiated the changes to local schools in their segregated neighbourhoods, and thus the two girls both entered new school classes where the minority students were the local majorities. Furthermore, both narrators construct this change of school as centrally important in their life stories. The story of how this process unfolded is the topic of the next section.

\section{Actively seeking to change schools}

Whilst the two girls had felt perpetually 'different' in their first (majority middle class-dominated) schools, they came to feel more at ease after changing to local minority-dominated schools. Like Sayyidah, Liyana's move reduced her heightened visibility as a minority. The change came about in the following way:

I simply decided to face my father and tell him that it was too hard, and that I wanted
to change the class I was in. [My father] said: "Why do you want to change school?
You can do it [i.e. manage without changing school]". Blah blah. But after I had talked
with him, my father could understand it. He knows of these problems - he can feel
that there is a dilemma inside a child between what the culture says, and what society
allows and the other children do. So in the beginning of the 8 th grade I moved to a
school closer by. It was nice. There were more girls from my background - Turkish
girls and Arabic girls (Liyana).

In her new context, Liyana's possibility for continuing to behave according to what the 'culture says' eased considerably, as she could now share her school life with classmates for whom the intersections between gender and ethnicity held the same implication for day-to-day practices as it did for her. Hence, in her new class, she found a sense of collective identity and shared cultural experiences. The ability to share day-to-day school life with group peers has been shown as central to the well-being of e.g. refugee students (Gay 2000; Oikonomidoy 2010).

Mahsa's $7^{\text {th }}$ grade stresses were of a different kind and arguably had less to do with her minority status per se, and more with the ways in which her own 'rebel' attitudes were threatening her educational aspirations. Mahsa related the story of her younger self's decision:

[Due to skipping classes] I didn't get much subject knowledge out of school. Then I thought: "Ay, this is enough. I only have 2-3 years left to pull myself together and improve my grades". I didn't really speak with anybody about it - it was just in my head. So I told my mother that I wanted to move to X-school [in the residential area], where my best friend was. I said it was because the school there was more serious. And [my mother] thought that was fine. 
According to her narrative, Mahsa's change of school sprang from her reflexive understanding of the dangerous path she was on, and she acted to avert an unwanted future while there was still time. With her change of school, she thus actively sought to alter the direction in which she was moving, a process that the next section lays out in greater detail.

\title{
Staying oneself or becoming another in order to stay on track
}

While Liyana's change to a class dominated by other 'foreign' girls made it easier for her to adhere to expected norms of Muslim female conduct and thus to remain the same, Mahsa's similar move was central for her ability to become someone else. As Mahsa says about her school change:

\begin{abstract}
I had been this rebel - hanging out on the street and smoking, so all my friends in the [new] class thought "here she comes!". We were all rough kids. But when I transferred, I just think it was a possibility for me to become someone else than the one I had had the possibility of being. So I became the top girl of the class (laughs a little). I turned up ten minutes to eight every morning. I still smoked cigarettes and disagreed with the teachers, but I did all my homework and was the one holding my hand up the most. In the $8^{\text {th }}$ grade we started getting grades, and I got the highest average in the class.
\end{abstract}

Deliberate school change is often termed a 'fresh start' (Juelskjær 2009), and Mahsa was indeed able to use her change in such a way: she changed from identifying as a 'rebel' (skipping school) to acting like a 'top girl' (arriving early, doing all her homework and being active in class). Entry into a new context - where the new teachers did not have negative expectations to her probably facilitated Mahsa's personal turn-around, as teachers' expectations are central to pupils' performances (Rosenthal and Jacobsen 1968).

Mahsa's move from a 'white' to a 'black' school may in itself also have facilitated her swift move to becoming the highest achieving student in her class: the change in context changed her relative position vis-à-vis her classmates. She thus went from being a negative deviant (due to both class and ethnicity) in the 'white' school into deviating positively in the 'black' school. This change occurred when Mahsa brought with her the manners and language she had learned in the 'white' middle class school during her first seven years of schooling. The skills she learned there most likely influenced her new teachers' categorisations of her, as Mahsa - in her new class - became the one conforming the most to the image of a 'good' student, which in the Danish public school system is modelled after a white middle-class norm (Gilliam 2006; Willis 1977).

Paradoxically, then, while low shares of ethnic minority pupils are generally associated with better school performance (Szulkin and Jonsson 2007), in individual cases such low shares may challenge the educational achievement 
of minority students who finds themselves to be the only ones of their kind in a given school class.

\section{Conclusion}

Individuals act, but they do not do so in circumstances of their own choosing. Thus this analysis documents how the interviewees' situated courses of actions' (Bertaux 2003) took them into perilous terrain during the tender years of their early adolescence - a time in life crucial for individual identity construction. The analysis also documents how intersections of ethnicity, gender and class can operate in different ways but with similar consequences of threatening the educational achievements of ethnic minority youth. In various forms, such challenges were also present in the broader interview material underlying this study, even though the 25 interviews were all conducted with individuals who managed to achieve educational success.

As the analysis shows, gender was implicated in the ethnic minority interviewees' aspirations for good educations. One underlying motive was that higher levels of education enables women to achieve greater levels of self-determination in both private and public spheres. But gender was also central in the schools' openness to the idea of ethnic minority girls or young women being 'good students', as when Mahsa became the top student in her new class. For ethnic minority boys, such openness may be harder to find, due both to the negative perceptions held by many teachers, and to the peer processes among marginalised boys at school which may actively undermine their abilities to perform well academically (Gilliam 2006).

Another central point of this article is the suggestion that the concept of vital conjuncture is analytically well suited for understanding the interplay between individual and society, including people's abilities to act, in circumstances not of their own choosing. Thus it is notable that whilst Liyana and Mahsa were each challenged in different ways, the horizons of the vital conjunctures present in their narratives were remarkably similar. This observation corroborates Johnson-Hanks' claim that the social patterns in horizons makes precisely these conjunctures suitable units of analysis (Johnson-Hanks 2002). Similar, too, was the agency that the two 14-year-old protagonists exerted as they sought to shape their own destinies. Their actions testify to their being much more than passive victims of discrimination, patriarchy, or both. Girls such as Liyana and Mahsa must be better understood as skilled social actors, possibly mature beyond their years as a result of their refugee experiences and the difficulties their parents had in coping with their new life circumstances.

The agency that both girls exerted was to move themselves in space, moves which in their cases contribute to our understanding of what may increase 
the educational success of ethnic minorities. The efficacy of these moves points to the close links between social and physical space, and how movement in one type of space may correlate to movement in another. Their complex manoeuvring between contexts of similarity and difference indeed aided the two girls in either becoming somebody else (as in Mahsa's case) or remaining the same (as in Liyana's case), through affecting the localized intersections of ethnicity, gender and class (Jenkins 2004).

A further point is that the timing of the vital conjunctures narrated by the interviewees were linked to changes occurring among the majority Danish youth. Marked changes in majority practices (e.g. drinking and partying) constitute well-described majority 'rites of passage' from around the age of 14 (Demant and Østergaard 2007), and encountering such changes in the 'contact zone' of school classes may intensify the pressures on already vulnerable ethnic minorities. While responses can both be either distancing the self from, or participating in such practices, both responses may adversely affect individual well-being and drain already strained resources. The life stories of this study thus suggest that we must also attend to the importance of such age-graded changes in majority practices when wishing to understand ethnic minority educational experiences in greater depth.

As a final note, these retrospective narratives were constructed from the narrators' present-day viewpoints of having completed educations in Denmark. However, other ethnic minorities end their 'Folkeskole' years in ways that preclude them from continuing in education, thus contributing to the differential educational attainments of ethnic minorities and the Danish majority (Christensen et al. 2014). This disparity calls further attention to the need for altering the multiple ways in which the share of pupils with ethnic minority background today structures school experiences to the detriment of ethnic minority students, who often have to struggle hard if they are to turn their aspirations for their futures into lived reality.

\section{References}

Ahmad, F. (2001) Modern Traditions? British Muslim Women and Academic Achievement. Gender and Education 13 (2): 137-152.

Ajrouch, Kristine J. (2004) Gender, Race, and Symbolic Boundaries: Contested Spaces of Identity among Arab American Adolescents. Sociological Perspectives 47 (4): 371-391.

Andersen, Jørgen G. (2008) Holdninger til uddannelse og arbejde blandt unge indvandrere, danskere og deres forældre. Odense: Syddansk Universitetsforlag. 
Andersen, Kathrine V. (2005) Problembørn, pædagoger og perkere - identitet og ambivalens $i$ mødet mellem etniske minoritetsbørn og systemet. Copenhagen: Sociologisk Institut, Københavns Universitet.

Archer, L. and Francis B. (2007) Understanding minority ethnic achievement. London: Routledge.

Bakken, Anders; Borg, Elin; Hegna, Kristinn and Backe-Hansen, Elisabeth (2008) Er det skolens skyld? En kunnskapsoversikt om skolens bidrag til kjønnsforskjeller i skoleprestasjoner. Oslo: NOVA - Norsk institutt of forskning om oppvekst, velferd og aldring, Rapport 2/2008.

Bertaux, Daniel (2003) The Usefulness of Life Stories for a Realist and Meaningful Sociology. In Biographical Research in Eastern Europe - Altered Lives and Broken Biographies, edited by R. Humphrey, R. Miller, and E. Zdravomyslova, 39-51. Hampshire: Ashgate.

Bourdieu, Pierre (1977) Outline of a Theory of Practice. Cambridge: Cambridge University Press.

Bourdieu, Pierre (1992) Language and Symbolic Power. Cambridge: Polity Press.

Christensen, Vibeke T.; Egelund, Niels; Fredslund, Eskild K. and Jensen, Torben P. (2014) PISA Etnisk 2012. Copenhagen: KORA.

Collier, V. P. and Thomas W. P. (2002) A National Study of School Effectiveness for Language Minority Students' Long-Term Academic Achievement. Berkley: University of California Press.

Darvishpour, Mehrdad (1999) Intensified Gender Conflicts within Iranian Families in Sweden. Nora: Nordic Journal of Women's Studies 7 (1): 20-33.

Demant, Jakob and Troels, Krarup (2013) Adolescent Alcohol Intoxication in Denmark: Policy, Culture, and Industry. Contemporary Drug Problems, 40 (2): 259-289.

Demant, Jakob and Jeanette, Østergaard (2007) Partying as Everyday Life: Investigations of Teenager's Leisure Life. Journal of Youth Studies 10 (3): 517537.

Espiritu, Yen L. (2001) We Don't Sleep around like White Girls Do: Family, Culture, and Gender in Filipina American Lives. Signs: Journal of Women in Culture and Society 26 (2): 415-440.

Ferguson, Ann (2001) Bad Boys: Public Schools in the Making of Black Masculinity. Michigan: University of Michigan. 
Gay, G. (2000) Culturally Responsive Teaching: Theory, Research, \& Practice. New York: Teachers College Press.

Gilliam, Laura (2006) De umulige børn og det ordentlige menneske - et studie af identitet, ballade og muslimske fxllesskaber blandt etniske minoritetsbørn i en dansk folkeskole. Copenhagen: Danmarks Pædagogiske Universitet.

Gitz-Johansen, Thomas (2006) Integration og sortering - hoordan den fleretniske skole samler og gør en forskel. Copenhagen: Samfundslitteratur.

Goffman, Erving (1986) Frame Analysis - an Essay on the Organization of Experience. Boston: Northeastern University Press.

Gross, Christiane; Gottburgsen, Anja and Phoenix, Ann (2016) Education systems and intersectionality. In Education Systems and Inequalities International Comparisons, edited by Andreas Hadjar and Christiane Gross, 5172. Bristol: Policy Press.

Gullestad, Marianne (1992) The Art of Social Relations - Essays on Culture, Social Action and Everyday Life in Modern Norway. Kristiansand: Scandinavia University Press.

Gullestad, Marianne (1996) Everyday Life Philosophers - Modernity, Morality, and Autobiography in Norway. Oslo: Scandinavian University Press.

Hällgreen, C. L. (2005) Working Harder to Be the Same: Everyday Racism among Young Men and Women in Sweden. Race, Ethicity and Education 8 (3): 319-342.

Heath, A. and Brinbaum Y. (2007) Explaining Ethnic Inequalities in Educational Attainment. Ethnicities 7 (3): 291-305.

Hervik, Peter (2004) The Danish Cultural World of Unbridgeable Differences. Ethnos 69 (2): 247-267.

Hibell, Bjørn; Ahlström, Salme; Balakireva, Olga; Bjarnason, Thoroddur; Kokkevi, Anna and Kraus, Ludwig (2009) Substance Use Among Students in 35 European Countries. Stockholm: The 2007 ESPAD Report.

Holstein, James A. and Gubrium, Jaber F. (2000) The Self We Live By. New York: Oxford University Press.

Jackson, Carolyn (2003) Motives for 'Laddishness' at School: Fear of Failure and Fear of the 'Feminine. British Educational Research Journal 29: 583-598. 
Jakobsen, Vibeke (2015) Uddannelses- og beskxftigelsesmønstre $i$ årene efter grundskolen, En sammenligning af indvandrere og efterkommere fra ikke-vestlige lande og etniske danskere. ung undersøgelse seksualitet Copenhagen: SFI - The Danish National Centre for Social Research, 15:17.

Jenkins, Richard (2004) Social Identity, (Second Edition). London: Routledge.

Jensen, Peter and Rasmussen, Astrid W. (2008) Immigrant and Native Children's Cognitive Outcomes and the Effect of Ethnic Concentration in Danish Schools. Odense: The Rockwool Foundation Research Unit and University Press of Southern Denmark.

Johnson-Hanks, Jennifer (2002) On the Limits of Life Stages in Ethnography: Toward a Theory of Vital Conjunctures. American Anthropologist 104 (3): 865880.,

Juelskjær, Malou (2009) En ny start: bevægelser i/gennem tid, rum, krop og sociale kategorier via begivenheden skoleskift. København: Danmarks Pædagogiske Universitets Forlag.

Keddie, Amanda (2011) Framing Discourses of Possibility and Constraint in the Empowerment of Muslim Girls: Issues of Religion, Race, Ethnicity and Culture. Race, Ethnicity and Education 14 (2): 175-190.

Koefoed, Lasse and Simonsen, Kirsten (2010) "Den fremmede", byen og nationen - om livet som etnisk minoritet. Roskilde: Roskilde Universitetsforlag.

Kragh, Lotte (2010) Kampen om anerkendelse, spillet om ære. København: Academic Books, Center for Sundhed og Samfund, Københavns Universitet.

Lauglo, J. (1996) Motbakke, med mer driv? Innvandrerungdom i norsk skole. Oslo: Ungforsk rapport 7/96.

Mills, C. W. (1959) The Sociological Imagination. Oxford: Oxford University Press.

Mooney, Nicola (2006) Aspiration, Reunification and Gender Transformation in Jat Sikh Marriages from India to Canada. Global Networks 6 (4): 389-403.

Nielsen, Chantal P. (2011) Immigrant Over-Education: Evidence from Denmark. Journal of Population Economics 24 (2): 499-520.

Nielsen, Lisbeth B. (2007) Ung 2006; 15-24 åriges seksualitet - viden, holdninger og adfæerd. København: Sundhedsstyrelsen.

Nusche, Deborah; Wurzburg, Gregory and Naughton, Brenda (2010) OECD Reviews of Migrant Education - Denmark. OECD. 
OECD (2006) Where Immigrant Students Succeed - A Comparative Review of Performance and Engagement in PISA 2003. OECD - Organisation for Economic Co-operation and Development, Programme for International Student Assessment.

Oikonomidoy, Eleni (2010) Zooming Into the School Narratives of Refugee Students. Multicultural Perspectives 12 (2): 74-80.

Pastoor, Lutine d. W. (2009) Learning Discourse: Classroom Learning in and through Discourse - A Case Study of a Norwegian Multiethnic Classroom. Oslo: University of Oslo.

Perreira, Krista M., Harris, Kathleen M. and Lee, Dohoon (2006) Making It in America: High School Completion by Immigrant and Native Youth. Demography 43 (3): 511-536.

Phoenix, Ann (2009) De-colonising Practices: Negotiating Narratives from Racialised and Gendered Experiences of Education. Race, Ethnicity and Education 12 (1): 101-114.

Pratt, Mary L. (1991) Arts of the Contact Zone. Profession 91: 33-40.

Prieur, Annick (2004) Balansekunstnere. Oslo: Pax Forlag.

Rheinländer, Thilde (2007) Unges livsstil og dagligdag 2006. København: Kræftens Bekæmpelse og Sundhedsstyrelsen.

Rosenthal, R. and Jacobson, L. (1968) Pygmalion in the Classroom: Teacher Expectation and Pupils' Intellectual Development. New York: Holt, Rinehart \& Winston.

Runfors, A. (2003) Mångfald, motsägelser och marginalisering: en studie av hur invandrarskap formas i skolan. Stockholm: Prisma.

Salikutluk, Zerrin (2016) Why Do Immigrant Students Aim High? Explaining the Aspiration-Achievement Paradox of Immigrants in Germany. European Sociological Review 32 (5): 581-592.

Sletten, Mira A. (2001) Det skal ikke stå på viljen - en studie av utdanningsplaner og yrkesønsker blant ungdom med innvandrerbakgrunn. Oslo: NOVA - Norsk institutt for forskning om oppvekst, velferd og aldring.

Statistics Denmark (2010) Indvandrere i Danmark 2010. København: Danmarks Statistik.

Staunæs, Dorthe (2003) De perfekte, de kedelige og de billige: om (hetero) seksualiseret etnicitet blandt 14-årige. NIKK Magasin 1. 
Støren, Liv A. and Helland, Håvard (2009) Ethnicity Differences in the Completion Rates of Upper Secondary Education: How Do the Effects of Gender and Social Background Variables Interplay? European Sociological Review 26 (5): 585-601.

Szulkin, R. and Jonsson, Jan O. (2007) Ethnic Segregation and Educational Outcomes in Swedish Comprehensive Schools. Stockholm: The Stockholm University Linnaeus Center for Integration Studies (SULCIS).

Tenenbaum, H. R. and Ruck, M. D. (2007) Are Teachers' Expectations Different for Racial Minority than for European American Students? A Metaanalysis. Journal of Educational Psychology 99 (2): 253-273.

Tranæs, Torben and Zimmermann, Klaus F. (2004) Migrants, Work, and the Welfare State. Odense: Syddansk Universitetsforlag.

Ulriksen, Lars; Murning, Susanne and Ebbensgaard, Aase B. (2009) Når gymnasiet er en fremmed verden: Eleverfaringer - social baggrund - fagligt udbytte. København: Samfundslitteratur.

Valentine, Gill (2007) Theorizing and Researching Intersectionality: A Challenge for Feminist Geography. The Professional Geographer 59 (1): 10-21.

Walker, Melanie (2005) Rainbow Nation or New Racism? Theorizing Race and Identity Formation in South African Higher Education. Race, Ethicity and Education 8 (2): 129-146.

Willis, Paul E. (1977) Learning to Labour. Aldershot: Gower.

Yuval-Davis, Nira (1997) Gender and Nation. London: Sage. 



\title{
Nation Divided: Building Identities through Bosnian History
}

\author{
ADNAN PECKOVIC \\ Lund University, Sweden
}

\begin{abstract}
This article focuses on the issue of promotion of ethnic divisions and producing collective narratives in primary schools in Bosnia and Herzegovina. Specifically, I will examine how the history textbooks (Bosnian, Croatian and Serbian) contribute to further dissolution of Bosnian society, how collective narratives are presented in the history textbooks and how the textbooks express the feeling of belonging to Bosnia and Herzegovina as a state. Findings show that the history curriculum (Bosnian, Croatian and Serbian) aims at supporting the 'us and them' politics through promoting group identity, through discrepancies in the history textbooks while describing important political events (the Islamisation of Bosnia and Herzegovina, the assassination of Duke Ferdinand, the start of WWI and WWII and especially the dissolution of Yugoslavia) through presenting members of the 'own' ethnicity as victims and 'others' as enemies. I argue that education in Bosnia and Herzegovina, especially in the field of history, supports further segregation of Bosnian society and that it needs quick reforms, so that young people from Bosnia and Herzegovina can participate in democratic and pluralistic society.
\end{abstract}

\section{Keywords}

nationalism, collective narratives, educational reforms, primary schools, history textbooks, segregation

\section{Introduction}

The war in Bosnia and Herzegovina from 1992 - 1995 has left many unsolved issues, even 18 years since it ended. One of those issues is segregated education. At this time there are three different school curriculums that are implemented in Bosnian schools. Society in Bosnia and Herzegovina is deeply divided between three sides that were in conflict during the war, Bosniaks (mostly Islamic), Croats (Catholic) and Serbs (Orthodox). Bosnia and Herzegovina today is divided into two entities (the Federation of Bosnia, which is mainly Bosniak and Croat parts, and the Serb Republic -the part of Bosnia where Serbs are in the majority). The Federation of Bosnia is then divided into 10 cantons, some with a Croat majority population and others with a Bosniak majority population. Each side is implementing their own school plan and programme on the territory where they are in the majority. It is important to mention that the cantons and the entity of the Serb Republic are in charge of the education system and the state has almost no influence over it.

The most common and vivid example of segregation in Bosnian education is the so called 'Two schools under one roof'. Students are taught in the same building, but are divided according to their ethnicity and are taught 
according to different curricula. Students also enter their schools through separate entrances and the schools have separate administrations.

Speaking of the International Community's (IC) role in education reforms in post-war Bosnia and Herzegovina it is important to mention that, although the Dayton Peace Agreement (DPA) Accords have covered the education sector in Annex 6, still education reforms were not assigned to any specific international organisation or institution to implement (Perry 2003: 42). Perry argues that four factors influenced the education reforms in Bosnia and Herzegovina:

- It was seen as a domestic issue

- There was no strong organisation to lobby for inclusion of education

- The short-term mind set of the international community during drafting the DPA

- Parties that have signed the DPA were not eager to hand over education reforms to foreigners, because politicians and citizens wanted to establish 'their own' education. (Perry 2003: 42-43)

Even though there was no official mandate for education reforms in Bosnia and Herzegovina there were high level efforts to pursue them. One of these is the 1997 Peace Implementation Council (PIC) meeting in Bonn where competent authorities were called to work together to ensure that all persons are educated according to their needs and in a manner which also contributes to tolerance and stability within a multi-ethnic Bosnia and Herzegovina, and to develop without delay an education programme consistent with these principles, in co-operation with the High Representative, UNESCO, the Council of Europe, the European Commission, the OSCE, UNICEF, the World Bank and other relevant organisations (Perry 2003: 47).

Finally, under the influence of OHR, OSCE, UNESCO, UNICEF and other international organisations, in 2002 the ministries of education from all the governing levels signed the statement that says: We, the ministries of education, will ensure that all children have access to quality education in integrated multicultural schools, education that has been freed from political, religious, cultural and other prejudices and discrimination and which takes into consideration the rights of all children (Husremović, Powell, Šišić and Dolić 2007: 16).

Still, education remains segregated.

This article will contribute to understanding of the issue of nationalism and segregation in Bosnian schools and its effects on current relationships amongst children of different ethnic and religious backgrounds in the education system in contemporary Bosnia and Herzegovina. 
The aim of this article is to explore values and concepts presented in the history textbooks and how different historical events are described in different history textbooks. The content analysis of history textbooks will provide me and the readers with information about if and in what way the history textbooks promote ethnic divisions amongst students in primary schools and in that way possibly contribute to educational reforms in Bosnia and Herzegovina.

The history text books analysed in this article serve to showcase how the educational system in contemporary Bosnia and Herzegovina is used to construct collective narratives amongst students in primary schools. They will also give us insight into how different ethnic groups perceive certain historical events that are generally seen with different eyes from the points of view of different ethnic groups. This is not in fact a new phenomenon in the history of Bosnia Herzegovina. In communistic Yugoslavia issues such as conflicts amongst ethnicities were 'swept under the carpet' and therefore not dealt with constructively, helping to foster nationalistic parties in the end of the 80s which brought these issues to the surface and produce a new conflict. These different points of view can be used to deepen the conflict amongst ethnicities in Bosnia and Herzegovina. Education, especially History as a school subject, plays a very important role in constructing these disintegrating or integrating narratives. As Radušić (2009: 1) has said education can be a disintegrating or an integrating factor in divided societies. In this sense education cannot be neglected as a peace forming factor and a security issue in Bosnia and Herzegovina.

\section{Theoretical perspectives}

\section{Nationalism}

Anthony D. Smith defines nationalism as an ideological movement for attaining and maintaining autonomy, unity and identity on behalf of a population deemed by some of its members to constitute an actual or potential 'nation' (Smith 1991: 73). Ernest Gellner defines nationalism as primarily a political principle, which holds that the political and the national unit should be congruent. (Gellner 2009: 73). Gellner also claims that nationalism is indeed an effect of industrial social organisation; it is not the only effect of the imposition of this new social form, and hence it is necessary to disentangle it from those other developments (Gellner 2009: 40). Especially important for this article is Gellner's argument that nationalism is a theory of political legitimacy, which requires that ethnic boundaries should not cut across political ones (Gellner 2009: 1). Eric Hobsbawm argues that the basis of 'nationalisms' of all kinds was the same: the readiness of people to identify themselves emotionally with 'their' nation' and to be politically mobilised as 
Czechs, Germans, Italians or whatever, a readiness which could be politically exploited (Hobsbawm 1989: 143).

\section{Nationalism and Education}

Mass public education system is an important tool for creating and maintaining mass ideologies such as nationalism. Smith argues that national identities also fulfil more intimate, internal functions for individuals in communities. The most obvious is the socialisation of the members as 'nationals and 'citizens'. Today this is achieved through compulsory, standardised, public mass education systems, through which state authorities hope to inculcate national devotion and a distinctive, homogeneous culture, an activity that most regimes pursue with considerable energy under the influence of nationalist ideals of cultural authenticity and unity (Smith 1991:16). Smith also claims that the task of ensuring a common public, mass culture has been handed over to the agencies of popular socialisation, notably the public system of education and the mass media (Smith 1991: 11). Especially affected are school subjects such as history where historical facts are often manipulated or even invented. Hobsbawm argues that history is the raw material for nationalist or ethnic fundamentalist ideologies as poppies are the raw material for heroin addiction (Hobsbawm 1997: chapter 1). He also argues that this is an essential element of these ideologies. If there is no suitable past, it can always be invented (Hobsbawm 1997: chapter 1). Apple argues that a curriculum is never simply a neutral assemblage of knowledge, somehow appearing in the texts and classrooms of a nation. It is always someone's selection or vision of legitimate knowledge (Apple 1993: 222). Usually the dominant group decides what legitimate knowledge is. Apple argues that there is a 'new hegemonic block' which is made of three different groups: Neo-liberalists, who want education policy to be based around economy, neo-conservatives whose main agenda is the cultural 'restoration' and the third one is the Christian fundamentalist group who want to return the Biblical tradition as the basis of knowledge and the fourth group as he says is made of the professional and managerial new middle class (Apple 2001: 2-3). In terms of multi-cultural education Apple argues that the dominant groups have taken mostly moderate and safe forms of multiculturalism and put them into curricula, so now in text books we have something that Apple has called 'mentioning' so the contribution of 'the other' is only mentioned (Apple 2001: 2-3). This way their status as 'the other' is guaranteed. He also argues that speaking of text books the political right had to compromise in order to maintain their leadership so they had to have some content about women, unions, and racial dynamics in their history (Apple 2001: 14).

Speaking of power sharing and relationships among different groups in multi ethnic societies Sidanius and Petrocik say that there are theories of intergroup 
relations that are referred to as group dominance models which support the thesis that societies tend to be organised as group based hierarchies, where dominant groups enjoy power, prestige and privilege while the subordinate social groups are poor (Sidanius and Petrocik 2000: 6). Dominant groups usually achieve hegemony through discursive practice and rarely through force. They achieve it through pushing towards particular identifications especially in post-colonial societies while promoting internal plurality were the state constantly seeks nation building projects (Durrani and Dunne 2004: 218).

\section{Ethnicity and Nation}

It is important at this stage to distinguish between ethnicity and nation. According to Horowitz ethnicity is a sense of collective belonging which could be based on common decent, language, history, culture, race and religion or some combination of these (Horowitz 1985 in Varshney 2009: 277). According to Varshney a nation is a group with territorial and political home (Varshney 2009: 277). In their article 'Europeanization in the 'other' Europe: writing the nation into 'Europe' education in Slovakia and Estonia', Deborah Michaels and Doyle Stevick mention two different concepts of nation: the ethno-cultural nation and civic nation (Michaels and Stevick 2009: 228). The ethno cultural nation is based on belonging in terms of particularistic ethnic and cultural attributes that are depicted as objective and organic rather than socially constructed. It is based on tribal origins and myths. In the civic nation concept there are no inherited threads of behaviour, but a common core of political values (Michaels and Stevick 2009: 228). Being a member of a 'tribe' or in other words belonging to one ethnicity has been of great importance for Bosnian people for centuries. And still today it shapes the politics of Bosnia. One could argue that the identity question in Bosnia has never been solved, from the Ottoman Empire until current times.

\section{Politics in Contemporary Bosnia and Herzegovina}

The political system as it is organised at the moment in Bosnia and Herzegovina is ethnically coloured and all three main ethnicities pursue efforts to maintain their positions. There is a small number of citizens of Bosnia that do not feel they belong to any of the main ethnicities, although they share the same background, but still call themselves Bosnians (in terms of belonging to the Bosnian state, and not only to one ethnicity). The number of these people cannot be determined at the moment, but it is generally considered that it is $2-3 \%$ of the population. Michaels and Stevick used the example of Slovakia and Estonia, who had a similar destiny to Bosnia and Herzegovina (besides from the war itself) (Michaels and Stevick 2009: 229). The key similarity between these three countries (Bosnia and Herzegovina, Slovakia and Estonia) is that they all had a very short amount of time of 
sovereignty and had over 40 years of communistic rule. They have described how the civic education textbooks promote Europe as a model for democratisation and not only Europe, but also the United States and the United Nations. The American Revolution and American presidents George Washington, Thomas Jefferson, and Abraham Lincoln replaced earlier images of socialist heroes such as Marx and Lenin (Jaksicsová 1995: 23, Kuírek et al. 1997: 19, Vavrová 1997: 211 in Michaels and Stevick 2009: 231).

Gavriel Salomon, professor at the University of Haifa in Israel, relying on Buner (1990) gives the following definition of collective narratives:

Collective narratives are the comprehensive collection of stories, beliefs, aspirations, histories, and current explanations that a group holds about itself and about its surroundings. Collective narratives are social constructions that coherently interrelate a sequence of historical and current events; they are accounts of a community's collective experiences, embodied in its belief system and represent the collective's symbolically constructed shared identity (Bruner 1990 in Salomon, 2004: 274).

If a country has three different narratives about historical events then it could become a problem. That is my main motivation to examine history textbooks and to discover if and in what way the same historical events are portrayed differently in different ethnic curriculums. Salomon argues that the ultimate goal of coexistence education ought to be the legitimisation of the other side's collective narrative and its implications (Salomon 2004: 278). This argument also comprises with Radušić's (2009) claim not to hold on to exclusive truths when teaching history, but to provide students with other points of view (Radušić 2009: 7).

Although other research has discussed the topic of segregated education in Bosnia and the school "National Group of Subjects" none of them have touched the issue of the importance of certain historical events for ethnic relations in Bosnia today and how it influences education today.

Questions that will help me answer the main question of this article are:

- How do the narratives in history textbooks express belonging of all three main ethnic groups to Bosnia and Herzegovina?

- How do the history textbooks present people of their own and other ethnic background?

How are new collective narratives constructed through history textbooks?

\section{Methodology and the focus of the research}

I will focus on analysing primary school history textbooks that are used in Bosnia and Herzegovina from the $5^{\text {th }}$ to $9^{\text {th }}$ grade. The aim of the content analysis of history textbooks is to examine eventual discrepancies in the points of view on several historical events or how they relate to each other. In 
analysing the history textbooks I will examine if they promote belonging to the Bosnian state, how they present "the others" and "own ethnic group", whether they serve to construct collective narratives and how they are presented. I will also examine the effects of possible discrepancies on ethnic relationships in Bosnia. This will be implemented through qualitative analysis of History textbooks by comparing the data and giving commentary to each segment of research.

The historical events I will examine are:

- The Islamisation of Bosnia and Herzegovina

- The beginning of World War I and the assassination of Arch-duke Franz Ferdinand

- World War II

- Dissolution of Yugoslavia

I believe that all four historical events are a source of conflict between the three main ethnic groups in Bosnia and Herzegovina and will argue that the teaching methods when these events are taught to children should be reexamined. All four of them are covered with mythos and are fuel to ethnic tensions in Bosnia and Herzegovina. During my discussions on the topics of discrepancies in the content of history textbooks with history teachers and reading through the history textbooks I have decided to focus this research on these four historical events mentioned above.

The textbooks that I have chosen for content analysis are textbooks that are currently used in Bosnian primary schools from $5^{\text {th }}-9^{\text {th }}$ grade and these are good representation of what is thought in terms of history in Bosnia. However, history textbooks are only part of the story of building collective narratives and historical mythos in Bosnia. Much more extensive research would include also other subjects from the "national group of subjects" (Geography, History, Language and Religious Education). However I believe that history textbook analysis can provide insight into whether the Bosnian education system is a designating or integrating factor in Bosnian society. Since educational system is in the obligation of political power we can also gain insight into political aims and goals and what the actual political agenda is in currant Bosnia.

In total I will analyse seven textbooks:

Bosnian curriculum: society from the $5^{\text {th }}$ grade of primary school, history textbook for the $7^{\text {th }}, 8^{\text {th }}$ and the $9^{\text {th }}$ grades of primary school 
Serbian curriculum: society from the $5^{\text {th }}$ grade of primary school, history textbook for the $9^{\text {th }}$ grade

Croatian curriculum: On the path of our past (history textbook for the $6^{\text {th }}$ grade)

I have chosen these specific textbooks for my content analysis because they discuss historical the events I have mentioned above.

\section{Results/Findings: Content analysis of the textbooks}

I have decided to use seven history text books. Four of them are from the Bosnian curriculum; two are from the Serbian curriculum and one from the Croatian curriculum. All seven are dealing with topics I wished to examine. After some informal conversations with history teachers I was advised to use these seven. I will examine the values and concepts presented in the textbooks.

\section{Ottoman Empire and Islamisation of Bosnia and Herzegovina}

The issue of Islam coming to Bosnia and Herzegovina is one of the historical events that is a source for tension amongst ethnic groups. In public discourse Bosnian Muslims today are 'Serbs who accepted Islam under the pressure of ottomans and therefore traitors'. This is something you can hear a lot and read on a lot on social networks.

In the society textbook for the $5^{\text {th }}$ grade (Serbian curriculum) the fall of Bosnian Kingdom under the Ottoman Empire was described in one paragraph. The author gave an introduction where they described the fall of Serbia under the Ottoman Empire describing the Kosovo battle (28.06.1389) as crucial battle for Serbia. The authors argue that Bosnia has fallen very quickly under the Ottomans and that the Ottomans have captured and killed Bosnian King Stjepan Tomšević. ${ }^{1}$ Further on the authors describe the life of people in Bosnia during the Ottoman Empire. Here they say that people did not have any rights, but only many obligations to the Empire, such as different taxes. ${ }^{2}$ Authors state that the worst of the obligations was what Ottomans called 'blood taxes' (I have not been able to find more appropriate translation) which meant that the Ottomans have taken healthy male children and prepared them to be Ottoman soldiers. Another chapter in this book discusses the people's resistance against the Ottoman Empire in Bosnia and Serbia. Authors argue that the hard life of Christians under Ottoman rule led

\footnotetext{
1 Pašalić, Stanojlović, Vukadin (2011) Poznavanje društva za 5 razred osnovne škole, Zavod za udzbenike i nastavna sredstva Istočno Sarajevo, p. 84 (Pašalić, Stanojlović, Vukadin (2011) Knowing your society for the 5th grade of primary school, Department for textbooks and learning material East Sarajevo).

2 Pašalić, Stanojlović, Vukadin (2011) Poznavanje društva za 5 razred osnovne škole, Zavod za udzbenike i nastavna sredstva Istočno Sarajevo, p. 85-87 (Pašalić, Stanojlović, Vukadin (2011) Knowing your society for the 5th grade of primary school, Department for textbooks and learning material East Sarajevo).
} 
to organisation of resistance and write that the first resistance movements against Ottomans were in Serbia (in 1804 and 1815). Serbian resistance has served as a model for the resistance in Bosnia. Biggest resistance battle in Bosnia happened in 1875 which has lasted for three years. It is notable that all the resistance leaders mentioned in this textbook were Bosnian Serbs. This textbook dedicates four pages to this event.

In the Bosnian society textbook (Bosnian curriculum) for the $5^{\text {th }}$ grade the fall of Bosnia under the Ottoman Empire was also only briefly described, but it is notable that the language used is different. Authors stated that it was in the $15^{\text {th }}$ century, when the Ottomans conquered Bosnia that medieval Bosnia fell apart. They said that Bosnia was completely conquered in 1463 and that Bosnia inside the Ottoman Empire had a special status in terms of administration. During the Ottoman Empire cities in Bosnia started to develop, so Sarajevo (capital of Bosnia and Herzegovina) became one of the biggest cities in the European part of the Ottoman Empire ${ }^{3}$.

In the history textbook for the $6^{\text {th }}$ grade (Croatian curriculum) it is written that Bosnia as an administrative unit inside the Ottoman Empire was formed in 15804. The authors say that the crisis that was present in whole Ottoman Empire was also present in Bosnia at that time. Accordingly the state had the need to increase its income so it gave land to local land owners who collected taxes for the state. The authors also argue that the life of Christians at that stage was very difficult, but still, the number of Christians has increased in the $18^{\text {th }}$ century. There were also other forms of discrimination towards Christians; they were not allowed to wear green (a traditional Islamic colour) and humble behaviour toward Muslims was demanded of them. The authors argue that with the Ottoman Empire came Islam. Islam has left the deepest roots in Bosnia, because the Church organisation was very weak at that stage. Everyone who converted to Islam could reach high functions in society and the economic situation of Christians in the villages was much worse that the once of the Muslims, Christians had to pay taxes, so there were many reasons to convert to Islam.

According to the $7^{\text {th }}$ grade textbook (Bosnian curriculum) Bosnia fell under the Ottoman Empire in 1463, but the whole Bosnian kingdom was not

\footnotetext{
3 Idrizović (2009) Društvo - Udzbenik za 5 razred osnovne škole, Federalno Ministarstvo za Obrazovanja i Nauke, p.29 (Idrizović (2009) Society textbook for the 5th grade of primary school, Federal Ministry for Education and Science, p.29).

4 Brdal, Madunić \& Lovrinović (2010) Tragom prošlosti - Udžbenik za 6-ti razred osnovne škole, Školska knjiga Zagreb i Školska naklada Mostar, p.167.

(Brdal, Madunić \& Lovrinović (2010), On the path of our history-History textbook for the 6th grade of primary school, School Book d.d Zagreb i School edition Mostar, p.167).
} 
occupied until 15925. Speaking about taxes, the authors argue that both (Muslims and Christians) had to pay almost the same taxes. The difference was that Muslims could take high social political positions and Christians could not. Muslims were obligated to go into the army and Christians were not. The authors claim that in Bosnia all religions enjoyed a great amount of freedom. As an example of that they give the charter of Mehmed II Fatih (Ottoman Emperor) from 1463 which granted freedom to Catholic priests to promote their religion.

\section{The beginning of the WWI and the assassination of the Archduke Franz Ferdinand}

On the 28.06.1914 Gavrilo Princip assassinated Archduke Franz Ferdinand and his wife. This event is considered as the beginning of WWI.

Textbooks from the Serbian curriculum say that Gavrilo Princip, member of an organization called 'Young Bosnia' (Mlada Bosna) assassinated Arch-duke Franz Ferdinand and his wife in Sarajevo (the Bosnian capital) on June 28, 1914 and that the Austro-Hungarian Empire used this event as an excuse to attack Serbia. Austro-Hungarian political leadership gives an ultimatum to Serbia to let Austro-Hungarian police implement the investigation in Serbia, which Serbia refuses. ${ }^{6}$ The assassins were quickly arrested and brought to trial. Three of Gavrilo's associates were hanged but since he was a minor he could not receive the death penalty. He was sentenced to 20 years in prison and died there, because he was tortured with hunger and beatings. After the assassination Austro-Hungarian authorities began a campaign against Bosnian Serbs. They started closing their shops, arresting Serb intellectuals, even Ivo Andrić. During this time many Serb intellectuals were accused of working against the Austro-Hungarian Monarchy and brought to trial and sentenced ${ }^{7}$.

In history textbooks from the Bosnian curriculum it is stated that the spark of war was lit by the assassination of Archduke Franz Ferdinand and his wife. That was done by Serb nationalists in Sarajevo on June 28, 1914. It is said that these nationalists were members of an organisation called 'Young Bosnia' (Mlada Bosna) which was supported by Serbia. Arch-duke Franz Ferdinand came to Sarajevo to observe a military manoeuvre. In history textbooks from

\footnotetext{
5 Dervišagić, Hadžiabdić, Mulić \&Mehić (2010) Historija-Udžbenik za 7 razred osnovne škole, Bosanska knjiga, p. 125 (Dervišagić, Hadžiabdić, Mulić \&Mehić (2010), history textbook for the 7th grade of primary schools, p. 125).

6 Pejić, Tešić \& Gavrić (2011) Istorija za 9 razred osnovne škole, Zavod za Udžbenike i nastavna sredstva Istočno Sarajevo, p. 55-56 (Pejić, Tešić \& Gavrić (2011), History textbook for the 9th grade of primary school, Department for textbooks and learning material East Sarajevo, p. 55-56).

7 Pejić, Tešić \& Gavrić (2011) Istorija za 9 razred osnovne škole, Zavod za Udžbenike i nastavna sredstva Istočno Sarajevo, p. 68-70 (Pejić, Tešić \& Gavrić (2011), History textbook for the 9th grade of primary school, Department for textbooks and learning material East Sarajevo, p. 68-70).
} 
the Bosnian curriculum the events which happened after the assassination were also described. After the assassination there was a big campaign against Serbs in Bosnia. Most Serbian property was confiscated and Serbian run stores were closed. After these events, representatives of all three ethnic groups visited the Austro-Hungarian authorities in Bosnia and lobbied for the campaign to stop. Even the Catholic and Islamic religious institutions lobbied for the campaign to stop. Austro-Hungarian authorities, on the 06. 02.1910, suspended the Bosnian assembly ${ }^{8}$.

\section{World War II}

Serbian textbooks say that in April 1941 the Yugoslav Kingdom was attacked by Germans: The Germans bombed Belgrade (the capital of Serbia) and between 2,300 and 4,000 citizens died. The Yugoslav Government retreated to Uzice (City in south - west Serbia). Muslim and Croat representatives retreated from the Yugoslav Government. King Petar left Yugoslav ground and escaped to London. That was the end of the first Yugoslavia. Hitler and his allies (Italians and Hungarians) divided Yugoslavia amongst each other ${ }^{9}$. Bosnia and Herzegovina was annexed to the Independent Croatian State which was under German rule. As German troops entered Zagreb (the capital of Croatia) people greeted them with happiness and threw flowers at German soldiers ${ }^{10}$. The aim was to extradite one third of the Serbs, one third should be converted to Catholicism and one third should be executed. Jews and Roma should also be eliminated quickly. In order to be supported by Muslim inhabitants of Bosnia they argued that Bosnian Muslims were actually Croats (Croatian flowers they said). Croatian army (Ustashe) started with mass executions of Serbs, Roma and Jews in concentration camps. In Jasenovac concentration camp alone (a small city in north Croatia) 700000 Serbs, Jews, Roma and antifascists were executed ${ }^{11}$. In Bosnia and Herzegovina a new Muslim militia was formed ${ }^{12}$. Serbian textbooks described the forming of the Independent State of Croatia as act of betrayal. As resistance to Germany and its allies Partisan Communist and Chetnic (Serbian military under the

\footnotetext{
8 Ganibegović, Durmišević \& Pelešić (2001) Historija-Povijest za 8 razred osnovne škole, Svjetlost Sarajevo, p.15-16 (Ganibegović, Durmišević \& Pelešić (2001) history textbook for the 8th grade of primary school, Svjetlost Sarajevo, p.15-16.

9 Pejić, Tešić \& Gavrić (2011) Istorija za 9 razred osnovne škole, Zavod za Udžbenike i nastavna sredstva Istočno Sarajevo, p. 102-105 (Pejić, Tešić \& Gavrić (2011) history textbook for the 9th grade of primary school, Department for textbooks and learning material East Sarajevo, p. 124-125).

10 Pejić, Tešić \& Gavrić (2011) Istorija za 9 razred osnovne škole, Zavod za Udžbenike i nastavna sredstva Istočno Sarajevo, p. 102-105 (Pejić, Tešić \& Gavrić (2011) history textbook for the 9th grade of primary school, Department for textbooks and learning material East Sarajevo, p. 127).

11 Pejić, Tešić \& Gavrić (2011) Istorija za 9 razred osnovne škole, Zavod za Udžbenike i nastavna sredstva Istočno Sarajevo, p. 102-105 (Pejić, Tešić \& Gavrić (2011) history textbook for the 9th grade of primary school, Department for textbooks and learning material East Sarajevo, p. 136).

12 Pejić, Tešić \& Gavrić (2011) Istorija za 9 razred osnovne škole, Zavod za Udžbenike i nastavna sredstva Istočno Sarajevo, p. 102-105 (Pejić, Tešić \& Gavrić (2011) history textbook for the 9th grade of primary school, Department for textbooks and learning material East Sarajevo, p. 131).
} 
command of Dragoljub Mihajlović) movements were formed. Both these movements express the wish to resist the occupation, Chetnics and the Government in exile also resisted the Partisans and its Communist leadership. In Belgrade in 1941 the Peoples Liberation Movement was formed and Josip Broz Tito was its leader. Now, we have two movements of resistance: the Chetnic movement (whose goal was to establish a new Serb state and return of the pre-war political system) and the Partisans (with the aim to establish a new Yugoslav state which would be a federal state and a socialist republic).

According to Bosnian textbooks Croatian ideology corresponded with German ideology. Independent Croatian State belong exclusively to Croats. Already in the formation of first days of the Independent Croatian State mass killings of Serbs, Roma and Jews had started, and in addition Muslim sand Croats that did not support the regime were executed. A small number of Bosnian Muslims joined the Croatian regime. Most Muslims, including the Islamic religious institution, condemned the mass killings. Several protest charters were published against mass killings. Some Bosnian Muslims, who did not accept the Croatian regime, lobbied for Bosnian autonomy under German protection and decided to protect them ${ }^{13}$. Most of them joined the Partisans at a later date. Together with the mass killing done by the Croatian regimes the Chetnics started mass killings of Bosnians, Muslims and Croats. Their goal was to renew Yugoslavia and establish 'homogenous Serbia' in it. Following that aim Chetnics had on several occasions executed mass killings of Bosnian Muslims in eastern Bosnia. Chetnics viewed the Partisans as a bigger threat than the Germans, so they started a war against Partisans too ${ }^{14}$. The Partisans' aim was to bring all antifascists together no matter what religious, national or other background they have. In order to defiantly defeat Partisans Hitler ordered a huge offensive against Tito's army. The German army, together with Croatian forces, Italians and Chetnics attacked Partisans in eastern Bosnia, but Tito managed to escape.

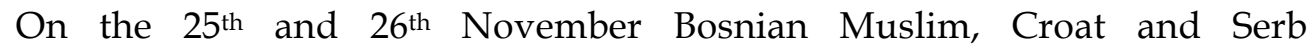
representatives in the Communist Party decided to renew the Bosnian state and include it the new Yugoslavia.

Croatian textbooks state that the Croatian Regime in many senses imitated the German regime. They opened concentration camps for Serbs, Jews and Roma. Not only Serbs, Jews and Roma were taken to concentration camps,

13 Ganibegović, Durmišević \& Pelešić (2001) Historija-Povijest za 8 razred osnovne škole, Svjetlost Sarajevo, p.85-86 (Ganibegović, Durmišević \& Pelešić (2001) history textbook for the 8th grade of primary school, Svjetlost Sarajevo, p.85-86.

14 Ganibegović, Durmišević \& Pelešić (2001) Historija-Povijest za 8 razred osnovne škole, Svjetlost Sarajevo, p.85 (Ganibegović, Durmišević \& Pelešić (2001) history textbook for the 8th grade of primary school, Svjetlost Sarajevo, p.85. 
but also those considered to be disloyal Croats. The Biggest concentration camp was Jasenovac where 48,000 Serbs, Jews and Roma were executed (Matkovic et al 2006).

\section{Dissolution of Yugoslavia}

According to Bosnian textbooks in Socialist Yugoslavia there was a great economic crisis. Inflation reached $80 \%$, Yugoslavia was so much in debt that it could not even pay the interest. Together with economic crises nationalism was also on the rise. Slovenia wanted more independence, Albanians wanted Kosovo to become a republic and Serbian politicians argued that Kosovo (part of southern Serbia with an Albanian majority) and Vojvodina (part of southern Serbia with a Hungarian majority) was Serbian territory ${ }^{15}$. In 1987 Slobodan Milošević became a leader of Serbian Communists. His aim was to make a centralised Yugoslavia with Serbian power which meant that all the main decisions would be made in Belgrade. During the 14th Assembly of the Communist Party, because of tensions with Serbian Communists, the Croatian, Bosnian and Slovenian Communists left the assembly. In the next period the formation and legalisation of other political parties began ${ }^{16}$. Most of them were ethnically and religiously coloured. The strongest parties in Bosnia were the Party of Democratic Action (Bosnian), Serbian Democratic Party (Serbian) and Croatian Democratic Union (Croatian). After Slovenia and Croatia declared independence the Bosnian assembly declared Bosnian independence, too. Serbian representatives left the assembly and declared the Serbian Republic of Bosnia and Herzegovina on one part of Bosnian territory. In the meantime, respecting the obligations towards the European Community, the legitimate Bosnian Government declared a referendum about Bosnian independence. The majority of citizens voted for an independent Bosnian state.

According to the Serbian textbook Serbia suffered a great loss through the Yugoslav Constitution of 1974, Kosovo (part of southern Serbia with an Albanian majority) and Vojvodina (part of southern Serbia with a Hungarian majority) received a great amount of autonomy. They had the entire political organ that one state had. Statehood of each republic in Yugoslavia has slowed down normal functioning of Yugoslav institutions. Serbian people on Kosovo were in a very difficult position since the Albanian separatists argued for Kosovo to unite with Albania. In all the Yugoslav republics new political parties were formed, and they were mostly nationalistic political parties. The Croatian nationalist party, Croatian Democratic Union, has won in the 1991

15 Šabotić 6 Čehajić (2012) Historija - 9 razred osnovne škole, NAM Tuzla, p. 179 (Šabotić 6 Čehajić (2012) history textbook for the 9th grade of primary school, NAM Tzla, p. 179).

16 Šabotić 6 Čehajić (2012) Historija - 9 razred osnovne škole, NAM Tuzla, p. 180 (Šabotić 6 Čehajić (2012) history textbook for the 9th grade of primary school, NAM Tzla, p. 180). 
elections in Croatia and they have decided that Serbs are not a constitutive nation in Croatia any more. Serbian assembly has after that pronounced Serbian Republic inside Croatia. In Bosnia Serbian and Croatian political parties contributed to the breakdown of Yugoslavia. In the year 1991 Serbian politicians implemented a referendum amongst Serbs about staying in Yugoslavia. The majority of Serbs wished to stay in Yugoslavia. On the basis of these results Serb politicians declared a Serbian Republic in Bosnia and Herzegovina, which would later be called Republic of Serpska. Bosnian and Croatian politicians have without the consent of Serbian politicians declared Bosnian independence and organised a referendum where the relative majority of Bosnians and Croats voted for an independent Bosnia. The international community recognised Bosnia as an independent state which led to a war between Bosnian Muslims, Serbs and Croats ${ }^{17}$.

\section{Concluding discussion}

In the concluding discussion I will give examples of how the history textbooks focus on only one ethnic group, the neighbouring countries and how they promote conflict amongst three different ethnicities in Bosnia and Herzegovina.

a) Focus on one (their own) ethnic group and neighbouring countries

In the society textbook for 5th grade the authors describe the fall of the Bosnian kingdom in one paragraph, but focus on the fall of Serbia under Ottoman rule and describe the Kosovo battle as the main battle for Serbia. The authors describe the lives of Christians under Ottoman rule and argue that the first acts of resistance against the Ottomans took place in Serbia. All the resistance leaders mentioned in the society textbook for 5th grade are Serbs. Authors in the Bosnian curriculum claim that Bosnia, as part of Ottoman Empire, had a special status. Authors of the Bosnian curriculum claim that during Ottoman rule cities in Bosnia started to develop. Authors in the Bosnian curriculum claim that life of Christians in Bosnia was difficult, but their number increased in the 18th century. Authors in the Bosnian curriculum claim that Christians in the villages were poorer then the Muslins and that was an important reason for Christians to convert to Islam. The focus on one nation was also clear when the textbooks describe the start of WWI. The Serbian textbooks argue that the assassination of Archduke Ferdinand was only an excuse to attack Serbia. In the Bosnian curriculum textbooks it is stated that, after the assassination, Austro-Hungarian authorities started a campaign against Bosnian Serbs, where most of their property was

17 Pejić, Tešić \& Gavrić (2011) Istorija za 9 razred osnovne škole, Zavod za Udžbenike i nastavna sredstva Istočno Sarajevo, p. 192-195 (Pejić, Tešić \& Gavrić (2011), history textbook for the 9th grade of primary school, Department for textbooks and learning material East Sarajevo, p. 192-195). 
confiscated. In the Bosnian curriculum textbooks it is also stated that representatives of all three ethnic groups lobbied to stop the campaign against Serbs. Serbian curriculum textbooks argue that Serbs have suffered the greatest loss and that Serbs in Kosovo were in a difficult position, because Kosovo Albanian separatists wanted to unite with Albania. These examples show us the promotion of one Serb nation on both sides of the border and promotion of Serbia as their homeland. For nationalists 'homeland' is crucial and it is usually argued that 'it is ours for centuries and generations'. Smith argues that it is, and must be, the 'historic' land, the 'homeland', the 'cradle' of our people, even where, as with the Turks, it is not the land of ultimate origin (Smith 1991: 9). We can also recognise a political effort to put all Serbs under one political umbrella where a certain set of values are promoted. As Smith argues "Finally, the legal equality of members of a political community in its demarcated homeland was felt to presuppose a measure of common values and traditions among the population or at any rate its 'core' community" (Smith 1991: 11). It is nation that is meant to be under a political community.

\section{b) Promotion of ethnic conflict}

Constant repetition of differences in culture, tradition and looking at certain historical events amongst ethnicities in Bosnia and Herzegovina by the history textbooks is promoting collective identity and presenting 'the other' as an enemy. Besides promoting a certain belief system and set of values it is raising some emotions amongst people by means of myths and facts that are historically not important. One example of that can be found in a Croatian curriculum history textbook for the 9th grade where it is stated that Croats greeted German soldiers with flowers as they marched in Zagreb (the Croatian capital). Since the Croatian army (Ustashe) in the Second World War has allied with Germans they are clearly presented as enemies. Hobsbawm argues that myth and invention are essential to the politics of identity by which groups of people today define themselves by ethnicity, religion or the past or the present borders of states, try to find some certainty in an uncertain and shaking world (Hobsbawm 1997). Presenting 'the other' as enemy is can be seen in a statement from the Serb history textbook where it is claimed that most Bosnian Muslims have joined the Ustashe (the Croatian army during the WWII) as Bosnia belonged to the Croatian Independent State and have together with Croats organised massacres of Serbs during WWII in Bosnia.

While conducting this research I have seen that the issue in Bosnian education in terms of religious education or secular education was never really solved. Since the Ottoman Empire onwards we had schools that were based on religious belonging and which were only for members of one ethnic group. The Austro-Hungarian Empire tried to establish secular schools in Bosnia, 
but people still attended religious schools in most cases. It can be assumed that the secular schools were too expensive. So the issue of ethnicity and religion has stayed in Bosnia since then. I have also noted that while talking to the teachers and school director they were open and discussed the topic without any breaks, but when it comes to following the curriculum they do not question it. It could be argued that this is the result of political pressure and that they do not want to make any waves, but still, they see what the problem is and where it is going.

What could actually be changed in history teaching in Bosnia? Several scholars, such as Edin Radušić have proposed the 'multi perspective approach', which would allow children to hear different sides of stories about the same historical events (Radusic 2009: 7). It would help to develop a student's critical thinking and save the student from exclusive truths (Radusic 2009: 7). What still needs to be investigated is the reaction of parents to it.

\section{References}

Anderson, David (1995) The Collapse of Yugoslavia: Background and Summary, Foreign Affairs Defence and Trade Group, Department of the Parliamentary Library.

Apple, W. Michael (1993) The Politics of Official Knowledge: Does a National Curriculum Make Sense? Teachers College Record. Volume 95 (2), pp. 222-241.

Apple, W. Michael (2001) Away with all the teachers: the cultural politics of home schooling, available at: http://nepc.colorado.edu/files/Apple.Away_.pdf

Bozic, Gordana (2006) Reeducating the Hearts of Bosnian Students: An Essay on Some Aspects of Education in Bosnia and Herzegovina, East European Politics \& Societies, May 2006(20) no. 2, 319-342.

Bryman, Alan (2004), Social Research Methods, Oxford University Press Inc. New York.

Cole, A. E. and Barsalou, J. (2006) Unite or Divide: The Challenges of Teaching History in Societies Emerging from Violent Conflict, Special report (United States Institute for Peace), available at: http://www.usip.org/sites/default/files/resources/sr163.pdf

Vladimir, Turjačanin; Kolenović-Đapo, Jadranka; Čehajić-Clancy, Sabina; Poljac, Ervin; Kordić, Milenko; Alić, Meliha; Inić, Branka; Radić, Nadežda UNICEF (2009) Divided schools in Bosnia and Herzegovina, available at: http://www.unicef.org/bih/Divided_schools_in_BHWEB_1.pdf 
Durrani, Naureen and Dunne, Máiréad (2010) Curriculum and national identity: exploring the links between religion and nation in Pakistan. Journal of Curriculum Studies, 42(2), 215-240.

Dženana Husremović; Powell, Steve; Šišić, Ajla and Dolić, Aida (2007) [Education in Bosnia and Herzegovina: What do we teach our children? Analysis of national group of school subjects textbooks]. Available at: http://www.erisee.org/downloads/2013/2/bh/Analysis\%20of\%20teachin g\%20books\%20for\%20national\%20subjects\%202007\%20BH.pdf (In Bosnian).

Gellner, Ernest (2009) Nations and Nationalism. Cornell University Press.

Hobsbawm, Eric (1989) Age of Empire. Vintage Books.

Hobsbawm, Eric (1997) On History [Kindle version]. New Press.

Karčić, Harun (2012) From Mekteb-I-Nuwwab to the Faculty of Islamic Studies: A Short History of Bosnia's Leading Islamic Educational Institution. Occasional Papers on Religion in Eastern Europe, 31(1), 4.

Kolouh-Westin, Lidija (2004) Education and democracy in Bosnia and Herzegovina. International Journal of Educational Development, 24, 495-509.

Wolff, Laurence and Breit, Elizabeth (2013) Education in Israel: The Challenges Ahead. The Gildenhorn Institute for Israel Studies.

Malcolm, Noel (1994) Bosnia: A Short History. New York: New York University Press.

Michaels, I. Deborah and Stevick, E. Doyle (2009) Europeanization in the 'other' Europe: writing the nation into 'Europe' education in Slovakia and Estonia. Journal of Curriculum Studies, 200(41: 2), 225-245.

Perry, Valery (2003) Reading, writing and reconciliation: Educational reform in Bosnia and Herzegovina. Working Paper No. 18. Flensburg: European Centre for Minority Issues.

Rabić, Nedim (2013) Manichaeism And The Bosnian Church. Sixth Biennial Convention. Bosniak Institute, Sarajevo, Bosnia-Herzergovina, September 26, 2013.

Radusic, Edin (2009) History Curricula Analysis: A part of the Bridging Histories in Bosnia-Herzegovina project. EUROCLIO (European Association of History Educators. 
Safia, Swimelar (2013) Education in Post-war Bosnia: The Nexus of Societal Security, Identity and Nationalism. Ethnopolitics: Formerly Global Review of Ethnopolitics, 12(2), 161-182.

Salomon, Gavriel (2004) A Narrative-Based View of Coexistence Education. Journal of Social Issues, 60(2), 273-287.

Shany, Payes (2013) Separate education and hegemonic domination: civil society challenges in the Arab-Jewish city of Jaffa. Intercultural Education, 24:6, 544-558.

Sidanius, Jim and Petrocik, John R. (2000) Ethnicity and National Identity: A Comparison of Three Perspectives. Paper Presented at the conference ReThinking Democracy in the New Millennium. Houston, Texas. Available at: http://www.uh.edu/democracy/sidaniust.pdf

Smith, D. Anthony (1991) National Identity. Penguin Books.

Torsti, Pilvi (2009) Segregated education and texts: a challenge to peace in Bosnia and Herzegovina. International Journal on World Peace, 26(2).

UNICEF Inoccenti Research Centre (2000) Two Faces of Education in Ethnic Conflict: Towards a Peace building Education for Children. Available at: https://www.unicef-irc.org/publications/pdf/insight4.pdf

Varshney, Ashoutosh (2009) Ethnicity and Ethnic Conflict. In Boix, Car and Stokes, Susan C. (eds.) The Oxford Handbook of Comparative Politics, pp 274-294.

Zhang, Y. and Wildemuth, B. M. (2009) Qualitative analysis of content. In B. Wildemuth (ed.) Applications of social research methods to questions in information and library science. Westport, CT: Libraries Unlimited, pp. 308-319. 


\title{
Empowering Others: Motives and Strategies Successful Ghanaian Women Adopt
}

\author{
DORIS ABENA AKYERE BOATENG \\ University of Ghana, Ghana
}

KWAKU OSEI-HWEDIE
University of Ghana, Ghana

I believe that it is up to us women to create the spaces that will empower other women. We have been side-lined for far too long...so it is about time we got up to fight for our fellow women (Study participant).

\begin{abstract}
This paper discusses the ways in which successful Ghanaian women seek to empower other women. It is important to explore this issue because literature on social change has mainly focused on the macro level social movements with little attention to the micro factors. Using a qualitative research design, 30 participants were purposively selected from academia, politics and trade for in-depth interviewing. The study revealed that in seeking to empower other women, successful women employ strategies such as mentorship, active participation in their communities, pushing for female-friendly work policies and advocating for youth development. In the post 2015 development agenda, attention must be paid to providing women with increased opportunities to empower other women at the micro level. These findings offer insights for social workers, policy makers, and future researchers.
\end{abstract}

\section{Keywords}

gender role, migrant families, educational empowerment

\section{Introduction}

In many development dialogues, empowerment is used to mean different things. Batliwala (2007: 557) argues that "empowerment is probably the most widely used and abused" word in development practice. Perhaps due to its historical roots in social justice and the redistribution of power such that communities are able to pursue their own developmental needs; the term empowerment has often taken a macro level approach. In many instances, when governments pursue empowerment programmes they are geared towards movements such as pro-life or pro-choice; or at opening up access for citizens to participate in civic activities and decision-making.

In an earlier work that examined the concept, Rowlands (1995) highlights the different meanings of empowerment in a variety of socio-developmental contexts. Among her most cogent arguments is that "empowerment is more than simply opening up access to decision making but also includes the processes that lead people to perceive themselves as able and entitled to occupy that decision-making space" (102). While it is important to pursue 
macro level development and empowerment processes, no government can attain complete development if it does not pay attention to how its members can also be empowered at the micro level.

For many decades, issues and discourses about women from developing countries and the global south have focused on their challenges and deficits, without a commensurate attention paid to their successes and triumphs. In many instances, women are categorised as a weak unit in need of rescuing, irrespective of their achievements within their given societies. In this regard, Mohanty (2003) argues that:

...in any given piece of feminist analysis, women are characterised as a singular group on the basis of a shared oppression. What binds women together is a sociological notion of the 'sameness' of their oppression ... This results in an assumption of women as an always-already constituted group, one which has been labelled 'powerless,' 'exploited,' 'sexually harassed,' etc., by feminist scientific, economic, legal and sociological discourses....The focus is not on uncovering the material and ideological specificities that constitute a particular group of women as 'powerless' in a particular context. It is rather on finding a variety of cases of 'powerless' groups of women to prove the general point that women as a group are powerless (338).

While Mohanty (2003) has succeeded in challenging this rather poor perception of women, especially, from developing countries, to date, women continue to be portrayed as victims of male dominance and passive onlookers of development processes. The time has come to draw attention to the triumphs of women and how they initiate, pursue and direct change in their families, workplaces and communities. In the light of the above, this paper utilises different conceptions of empowerment to explore the motives and strategies that successful women from three different fields employ to empower other women in their localities and society at large. However, there is a dearth of literature on women's success stories in the African and Ghanaian contexts. This study, therefore, contributes to the existing body of knowledge on the ways through which women drive development issues in Ghana by highlighting the lived experiences about how some Ghanaian women have served as agents of change.

Adopting a social justice practice approach, the paper presents the lived experiences of a cross-section of successful Ghanaian women who are working in diverse ways to create spaces within which other women are empowered. Following the introduction is the review of the literature on the relationship between empowerment, agency and development. This is followed by the methodology adopted for the study after which the findings of the study are presented. The discussion of the findings and their implications for social work practice are then presented. 


\section{Conceptualising Empowerment}

It is believed that when people are empowered, they are able to participate in, contribute to, and benefit from growth (Eyben, Kabeer, and Cornwall 2008). Kabeer (1999) asserts that empowerment is about the process by which those who have been denied the ability to make strategic life choices acquire such ability. But empowerment is not an end in itself. What people do with the acquired ability; how they make choices to influence or enhance their own lives and those of others; and how this ability is manifested when acquired, are all important factors that are worth considering in the empowerment discourse.

According to the empowerment principles of Paulo Freire (1973) people are able to empower themselves when they acquire knowledge about the conditions that oppress them. Freire (1973) believed that when people think critically about their education, it would allow them to deeply examine their reality. He, therefore, advocated that through empowerment, people should be able to acquire needed skills, build confidence, and create opportunities for individual and collective action (Delp, Brown, and Domenzain 2005). With education - not necessarily formal, classroom education, but by giving access to information - people can empower themselves if they use the critical view afforded them. Thus, they can gain an understanding of existing social, economic, and political forces that affect their lives and take the necessary steps to change their circumstances.

The World Bank (2005), however, emphasises that empowerment is more than participation in decision making because 'it must also include the processes that lead people to perceive themselves as able and entitled to make decisions'. Therefore, seeking to empower women, in whatever form it would take - be it in giving them access to participate in decision making or to credit facilities, or even in income generating skills - without seeking to make fundamental changes to the cultural and structural barriers that exist in their societies becomes a fruitless exercise.

Karl (1995) explains that empowerment is a word widely used but seldom defined. To her, long before the word became popular, women were speaking about gaining control over their lives and particularly in the decisions that affect them in the home, the community, government and in the international development policies. She defines empowerment as "a process of awareness and capacity building leading to greater participation, to greater decisionmaking, power and control and to transformation action" (p. 13). Empowerment of women, therefore, is about creating awareness about oppressive conditions, helping women to acquire the necessary tools to overcome the oppression and building on that to transform their own lives. 
Empowerment should not be understood as one person or group giving power to another.

In an effort to conceptualise empowerment, Kabeer (1999) asserts that it is the process by which those who have been denied the ability to make choices acquire such ability. She explains that empowerment, therefore, entails a process of change, in that a person who hitherto did not have the ability to make critical life choices should experience the change that now affords him or her the ability to make such choices. In this regard, a person can be said to be empowered if he or she acquires or expands the ability to make strategic life choices within a context where they had been previously denied. Empowerment, therefore, cannot be reduced to a single aspect of process or outcome but rather, on how women are able to exercise choice, and the outcome always depends on the individual, class, time and space.

\section{Empowerment, Agency and Development}

Without a doubt, women's empowerment and agency are precursors to development. This has resulted in many governments and development agencies prioritising women's empowerment programs in national development projects (Cornwall and Anyidoho 2010). Sen (2001: 506) also draws linkages between development and freedom, arguing that "freedom is both the primary objective of development and its principal means". When people are free to make decisions about and pursue things which they consider to be of value to them without fear of retribution or violence, they are said to exercise their agency. Sustainable human agency is without a doubt the most powerful engine of development.

Since the early 1990s when governments around the world begun implementing what was known as the Washington Consensus, there has been an accompanying pursuit of the principles of human freedom and dignity, perhaps as an unspoken admission that without freedom and dignity, efforts at development will not succeed. However, as Kabeer (1999) points out, empowerment is not merely about giving power to a group of people who are otherwise disempowered, but is rather multidimensional. It involves both the personal and public aspects of women's lives: their sense of self-worth and social identity, as well as the ability to exercise agency within their given societies. It is after women have achieved these that any country can boast of attaining gender parity and empowering its women.

The government of Ghana admits in its Strategic Implementation Plan of the Ministry of Women and Children's Affairs (now Ministry of Gender, Children and Social Protection) that major sources of women's subordination in Ghana are "the social constructions of womanhood centred on reproductive roles which restrict women's access to productive resources 
such as credit, land, training and education, and also to decision-making processes" (Anyidoho and Manuh 2010, 268).

Rowlands (1995) asserts that empowerment should be about bringing people who are outside the decision-making process into it by putting a strong emphasis on access to political structures and formal decision-making. To become fully empowered, many women need to have the burden of productive and reproductive responsibilities reduced, access to higher and quality education and health expanded, have the expertise to make decisions on their sexual and reproductive health issues and effectively participate in the civic affairs of their societies. In addition to these, women also need access to credit and safety nets to be able to compete favourably with men and remove the unequal sources of power and ideologies that perpetuate women's subordination (see Kabeer 1997).

\section{Methodology}

The general target population for this study was successful Ghanaian women. However, selection of participants was restricted to the fields of academia, politics and trade. These three categories of fields were selected because they were either regarded as male dominated (in the cases of academia and politics) or had a large pool of women concentrated in this field (trade). All study participants were purposively selected based on the positions held in the fields from which they were selected.

In academia, female academic staff who occupy such senior positions as lecturers, heads of departments, schools and faculties, as well as senior administrative positions such as deans, provosts and vice-chancellors were selected while in politics, women in key government positions and heads of public institutions were selected. Women in trade consisted of entrepreneurs and exporters of goods as well as women who had businesses in more than one country. A total of ten women from each field were selected for in-depth interviews. These interviews focused on eliciting information from participants about their socio-demographic backgrounds, experiences while growing up, and how these experiences shaped their motives for seeking to empower other women. In addition, the strategies they employed while doing so were explored. All interviews were audiotaped with the permission of the participants.

The recorded in-depth interviews were transcribed, coded, and analysed thematically based on the objectives of the study. In doing so, the interviews were played and listened to several times to accurately capture the data which was later transcribed. By inductively analysing the data, dominant themes emerged devoid of the restraints imposed by structured methodologies (Thomas 2003). These emerging themes were compared 


\title{
John Fowles's The French Lieutenant's Woman as a New- Historical Novel
}

\author{
ELA IPEK GUNDUZ \\ University of Gaziantep, Turkey
}

\begin{abstract}
As an example of neo-Victorian fiction, John Fowles's novel The French Lieutenant's Woman (1969) deviates from the classical historical novel by deploying different narrative notions destabilising the notion of 'history'. The slippery notion of the 'historical' (in terms of its being fictional/artificial and varied) especially in its construction of a presentist Victorian trope is its main neo-Victorian qualification. By involving a modern criticism of the Victorian ideology as well as the similarity of the problems, such as the hypocritical attitudes of middle class people and the exploitation of sexuality encountered in the twentieth and even twenty-first centuries, The French Lieutenant's Woman becomes a leading example of neo-Victorian fiction. The main aim of this article is to show how The French Lieutenant's Woman represents a retrospective view made possible by history by providing a current view about Victorian times. Through the novel's maintaining a two-dimensional historicity, the contemporary view mirrors the past.
\end{abstract}

\section{Introduction}

In the late twentieth-century, new historical novels began to employ different narrative modes and destabilise the notions of 'history' and the 'historical' of the traditional historical novel. John Fowles's The French Lieutenant's Woman (1969) is the leading example through which the slippery notion of the 'historical' in terms of its being fictional/ artificial is depicted, especially in its construction of a presentist ${ }^{1}$ Victorian trope. In this novel, Fowles positions the contemporary fictional use of Victorian topics (such as sexuality and bourgeois hypocrisy) as something which is both a serious source of continuing cultural problems in contemporary society and a popular appeal attracting the interest of contemporary readers. Its protagonist Charles is a young, middle-class Englishman who is attracted to the eponymous Sarah. Sarah is a young woman who experiences a process of change in Lyme Regis in Dorset in the West of England, as a result of her seduction and betrayal by a French officer. Through their relationship, Fowles relates the Victorian to the contemporary.

At the beginning of each chapter the novel uses epigraphs from Victorian texts that exist with comments about them by a narrator with a contemporary perspective. The narrator, who has a consciousness beyond his times, makes the novel neo-Victorian presenting the recognition of the Victorian period from the eyes of the present. By providing a current outlook on the Victorian era, the narrative maintains the retrospective view "made possible by history

\footnotetext{
1 "In literary and historical analysis, presentism is the anachronistic introduction of present-day ideas and perspectives into depictions or interpretations of the past" https://www.revolvy.com/main/index
} 
and in this way facilitate[s] the illumination of the past in the optic of the present" (Cooper 1991: 105). This two-dimensional historical perspective paves the way to reflect the past from the mirror of the present. This interpenetration of the past and the present makes up the historical framework of the novel. Fowles explains the process he experiences as a writer in creating his novel inspired from Victorian times:

The novel I am writing at the moment (provisionally entitled The French Lieutenant's Woman) is set about a hundred years back. I don't think of it as a historical novel, a genre which I have very little interest. It started four or five months ago as a visual image. A woman stands at the end of a deserted quay and stares out to sea... It was obviously mysterious. It was vaguely romantic. It also seemed, perhaps because of the latter quality, not to belong to today... The woman had no face, no particular degree of sexuality. But she was Victorian; and since I always saw her in the same static long shot, with her back turned, she represented a reproach on the Victorian age. An outcast. I didn't know her crime (Fowles 1998: 147).

In this explanation Fowles declares that he is not interested in writing a historical novel but somehow, inevitably, the novel turns out to be so because of the story of its Victorian protagonist. Turning to the past, Fowles asserts:

In the matter of clothes, social manners, historical background and the rest, writing about 1867 is merely a question of research. But I soon get into trouble over dialogue, because the genuine dialogue of 1867 is far too close to our own to sound convincingly old. It very often fails to agree with our psychological picture of the Victorians - it is not stiff enough... This is the greatest technical problem I have; it is hard enough with modern characters, and doubly so with historical ones... "If you want to be true to life, start lying about the reality of it" (Fowles 1998: 150).

Fowles, in spite of his denial of writing an example of the historical novel in The French Lieutenant's Woman, explains his methods in imitating the Victorian reality through language, manners and costumes. The outcome is a representation of Victorian life, thus its qualification of historical writing is through fictionalisation. The separation between history and fiction is questioned by the distance between the past and the present that gives him the chance to present historical material in a critical way. In The French Lieutenant's Woman Fowles's characters try to get rid of historical constraints, which are especially threatening to them in terms of their existence and gender perceptions coming from the specific era in which they belonged. Thus, the novel could be regarded as Victorian because of the era it is reflecting and the literary examples it presents and, at the same time, it is modern because of the psychological dilemma Sarah and Charles experience ${ }^{2}$.

\footnotetext{
2 "The plot structure of The French Lieutenant's Woman enacts the dialectic of freedom and power that is the modern existentialist ... answer to Victorian ... determinism. But it requires that historical context in order to interrogate the present (as well as the past) through its critical irony" (Hutcheon, A Poetics 45).
} 
When contemporary contributions to literary genres are concerned, it is disputable whether The French Lieutenant's Woman should be counted as a new historical novel or a historiographic metafiction (or both). In the evaluation of neo-Victorian fiction, historiographic metafiction comes, at first, as a predecessor to neo-Victorian novels as new historical novel because the latter gets benefit from the former and also sometimes they go beyond its limits (they turn out to be faux Victorian ${ }^{3}$ for instance). Thus, as the first step towards tracing the generic mechanism of the new historical novel, including the neo-Victorian novel, The French Lieutenant's Woman should be examined as historiographic metafiction.

The French Lieutenant's Woman is regarded as the "first British historiographic metafiction" 4 because of its separation of the historical and literary sources and the inclusion of "a godlike author who attempts to bestow freedom on his own characters" (Holmes 1997: 206). The French Lieutenant's Woman is historical both because of its employment of narrative conventions derived from earlier periods and because it is set in the past. Fowles's narrator "juxtaposes nineteenth and twentieth century modes of thought, feeling, and behaviour, enabling each to comment upon and qualify the other" (Holmes 1997: 208). He does not; then, attempt to show that the world he is presenting is real rather than a human production. That is, through emphasising its own artificiality, it also subverts the so-called realism of Victorian novels. Fowles shows how artificial those realist novels were by using realistic conventions and by emphasising "the strangeness of the Victorian world" (Holmes 1997: 209). Fred Kaplan asserts that Fowles's portrait of the Victorian era comes through literary works rather than the historical documents:

The history, then, is more in the fiction than in the fact, more in the literary products of the age than in the factual documents of the historians. Fowles has succeeded in writing a fiction, a historical novel... revealed through the period's imaginative literature... It is as if Fowles wants to redefine facts in the light of his attempt to relate the past to the present. The past that exists, in this case the Victorian past, is the product of our present immersion in the only aspect of the past that still has life, its art (111).

Fowles, by depending on the literary history of the Victorians re-creates the Victorian with the help of its unique literary works rather than trusting the official history. Subsequently, he both recreates the past as neo-Victorian and

\footnotetext{
3 "The faux Victorian novel is a fascinating area of tension between the Victorian and the contemporary, a hybrid space of mimicry, camouflage and assertions of difference" (Voigts-Virchow 2009: 112). "In particular the faux London lowlife slang of Waters's character narrators, therefore, appears as a curious mixture of historically contingent and contemporary, muddling notions of an indigenous and alien Victorian cant. Unlike Fowles, Faber, and Byatt, Waters does not provide a contemporary twenty-first-century consciousness as a frame or distancing device" (Voigts-Virchow 2009:120).

4 Linda Hutcheon (1988) defines "historiographic metafiction" as: "By this I mean those well-known and popular novels which are both intensely self-reflexive and yet paradoxically also lay claim to historical events and personages: The French Lieutenant's Woman, Midnight's Children, Ragtime, Legs, G., Famous Last Words" (5).
} 
proves the fictionality of history. As Linda Hutcheon asserts, the result is "the real and the imaginary, the present and the past merge for the reader" (Hutcheon 1988: 84). Thus, the imaginary could also be the truth. The readers are both aware of the fact that they are reading an imitation of the Victorian novel, and they know that they are living in an era when Victorian novels are no longer written. In that respect this novel is "a Victorian novel that is a contemporary novel about the Victorian novel" (Eddins 1976: 217).

The contemporary narrator looks back on Charles Smithson who is an aristocrat with his fiancée, Ernestina Freeman, who is the daughter of a London merchant visiting her aunt in Lyme Regis in 1867. Charles is a male figure who makes researches about fossils in Ware Common where he encounters Sarah Woodruff, an exceptional and intelligent girl suffering from her abandonment by a French naval officer. At that moment, the narrator says, "the whole Victorian age was lost" (81), since Charles became obsessed by the desire to help Sarah. When his uncle disinherits him by marrying, Charles feels financially inferior to his fiancée, and he responds to Sarah's plea for help when she is dismissed from the employment of Mrs. Poultney who is the moral tyrant of Lyme Regis. Charles's friend Dr. Grogan, who is a doctor, warns him against Sarah, but Charles plans an appointment with her in Exeter on the way back from a confrontation with Tina's father in London. After visiting him, Charles feels insulted by Mr. Freeman's offer for a position in his firm and visits a brothel. Then he decides not to see Sarah to carry out his promise to Ernestina "and so ends the story" (348).

Fowles then turns back to "the moment of choice" (351) and Charles orders Sam (his servant) to stop at Exeter, where he experiences a ninety-second sexual encounter with Sarah and discovers that she is a virgin. Her story of seduction by the French lieutenant was a lie, and Charles resolves to marry her. He returns to Lyme Regis and horrifies all the proper Victorians by breaking off his engagement to Ernestina, but Charles cannot find Sarah, because the vengeful servant Sam sabotages the delivery of his letter and he is rewarded with a position in Mr. Freeman's London shop. At this point, the narrator rejects the option of leaving the story with an open ending and proceeds to two conclusions through which the version is determined by a flip of a coin. After his search for Sarah fails, Charles travels for two years until his solicitor sends him a telegraph in America to say that Sarah has been found. In May 1869, he encounters Sarah again and he is shocked to find that she has become an amanuensis and a model for D. G. Rossetti but Fowles switches to a second ending in which Charles is outraged at the discovery of her lies and at her declaration, "I cannot love you as a wife must" (477). He feels painfully reborn and alone goes "out again, upon the unplumb'd, salt, estranging sea" of life (480). 
When the subject matter is taken into consideration, the novel initially seems to have a typical Victorian plot: Charles leads a comfortable life in high Victorian society and chooses a wife to be married because it is time for him to find someone in his life. This candidate is the most proper figure who could act the perfect role for this conventional Victorian story. Thus, in the first ending with Ernestina; "he felt himself coming to the end of a story" (339) that preserves the status quo (a significant idea in Victorian thought). Still, both because Charles has doubts in his inner world and the existence of Sarah, this traditional/expected Victorian version of the story is impossible because "with [Sarah] anything can happen" (Tarbox 1990: 62). Charles than understands that he does not love Ernestina, she has been an idea of Victorian respectability in which he believed he wanted to participate.

The first twelve chapters present the characters, the subject matter, and the necessary information about the Victorian age. The readers become aware of the circumstances of the 1860s step by step. In the end of Chapter Twelve, to the question: "Who is Sarah? Out of what shadows does she come?" Chapter Thirteen answers it with the subversion of the authority of the author: "I do not know":

I do not know. This story I am telling is all imagination. These characters I create never existed outside my own mind. If I pretended until now to know my character's minds and innermost thoughts, it is because I am writing in (just as I have assumed some of the vocabulary and voice of) a convention universally accepted at the time of my story; that the novelist stands next to God. He may not know all, yet he tries to pretend that he does (41).

Fowles constructs the novel as a historical novel by producing a subverted version of a Victorian novel. The subverted Victorian novel is without structure: its ending may come in the middle, at the end, or it may not come at all. Fowles also destroys the sense of reality created by the events in the novel. He does this by disrupting certain scenes and declaring them as artificial: "I have pretended to slip back into 1867" (409). The narrator questions his authority by losing control of his characters (such as when Charles disobeys his orders, or when Sarah disappears and even he does not know where she is). What the narrator does is to discredit himself as an author having authority. He tries to distinguish himself from those authors who pretend to be gods. He assesses his relationship to his story and his reader when he gets on the train with Charles:

Fiction usually tends to conform to the reality; the writer puts the conflicting wants (of his characters) in the ring and then describes the fight - but in fact fixes the fight, letting that want he himself favours win... But the chief argument for fight-fixing is to show one's readers what one thinks of the world around one ... I continue to stare at Charles and see no reason this time for fixing the fight upon which he is about to engage (406). 
The narrator establishes Sarah's dramatic story by bringing it to a point of climax, and the reader is given the chance to make their own explanations about ongoing events. As for the endings, neither ending is satisfactory: the first is sentimental and traditional; the second is bleak and fails to satisfy the reader's expectations. Fowles demonstrates that he has only chosen two from the number of the possible endings and stresses the arbitrariness. In that respect, he refuses to end his own story. Through these variations Fowles shows that this is not a Victorian novel and cannot have a conventional close ending. Since Sarah is the protagonist, the second ending granting freedom would be a probable ending for a modern novel.

Fowles gives his novel the qualification of 'historical' with quotations and references to Victorian thinkers, but through the narrator's tricks all pretence of writing 'history' (in a conventional way) collapses. The intruding narrator is also always there-not only for manipulating the time and plot developments but also to show that this is a new historical novel which recreates the past in present. Fowles even warns himself during the writing of the novel. He cautions himself to remember:

You are not trying to write something one of the Victorian novelists forgot to write: but perhaps something one of them failed to write. And: Remember the etymology of the word. A novel is something new. It must have relevance to the writer's now-so don't ever pretend you live in 1867: or make sure the reader knows it's a pretence (409).

Thus, this novel is not an attempt to create a pseudo-Victorian novel but to create an authentic version of it from a twentieth-century perspective. In this respect, it becomes a neo-Victorian novel creating an original Victorian story with the help of the modern narrative perception.

In contemporary presentations of self-reflexive neo-Victorian novels, sexuality and economics somehow turn out to be the concepts that connect the Victorian and the present, both because of contemporary people's desire to explore the hidden truths lying behind the suppression of those times, including the sparks of sexual and consumerist desires restricting all individual attempts. Specifically, sexual desire is a theme highlighting the Victorian man and woman's psychological struggle with forbidden lusts. In that respect The French Lieutenant's Woman is an intermediary sample between the Victorian and contemporary times because of its very deployment of sexuality as a theme both refrained from and making the parallelisms between the past and the present. It experiments with the generic conventions of the classical historical novel by providing varied accounts of the past as alternatives to official history and novel writing.

Victorian sexuality has been a dominant theme for neo-Victorian novels as a form of exposing the Victorians as hypocrites obsessed with sexuality. As 
Michel Foucault indicates this Victorian hypocritical attitude towards sexuality continues: "Sexuality was carefully confined; it moved into the home," and it is positioned to fulfill "the serious function of reproduction" (Foucault 1978: 3). Fowles's female protagonist transgresses these historical prejudices. She is assumed to be the French Lieutenant's "whore" by the Lyme Regis population, but she is actually a virgin whose only sexual encounter is with the protagonist, Charles Smithson. Her dilemma (and Charles's) at the end of the story is whether she consents to a conventional marriage, or becomes a sort of New Woman living in the pre-Raphaelite, Rossetti household, and perhaps, bringing up Charles's child on her own.

The effects of the repression of female sexuality and the morality of Victorian society are questionable in The French Lieutenant's Woman. This ambiguous sense of the perception of sexuality and the position of women are embodied in Sarah ${ }^{5}$. She expresses her thoughts about her own sexuality directly but she continuously suppresses her desires. Thus, both Charles and the readers fail to comprehend her behaviour. For instance, in the final pages Charles sees Sarah's nature as more cruel than the effects of the social prejudice that he hates. Even when driven by mutual sexual desire, sexuality is a domain where Charles and Sarah's own levels of anxiety, and denial, seem ambiguous. Fowles's characters struggle within the unsolved perceptions of love and sexuality.

Some neo-Victorian novels depicting the hidden tropes of sexuality benefit from romance as a genre. As Fowles explains, there is an inspiration that has hauntedly taken him and forced him to create a Victorian world. Surprisingly, this figure coming from the Victorian times is a marginalised woman. Sarah is the very figure affecting the inspiration and the production of the novel in which she exists. Because of its inspiration - a female figure from Victorian times - this novel turns out to be a work of romance ${ }^{6}$ (or historical romance ${ }^{7}$ ) written in a neo-Victorian fashion. Neo-Victorian fiction,

\footnotetext{
5 Sarah is entrapped by the constraints of the Victorian period and the gender role expected of her. Actually, being enigmatic as a female figure is conventional in literary tradition, but through the narration of the novel Sarah turns out to be a mystery beyond the typical imperceptible woman: Charles's interior motivations could be traced by the narration but Sarah is marginalised/modernised from the Victorian era (whereas Mrs. Poulteney and Ernestina remain in the Victorian period avoiding Sarah). In that respect both characters despite their marginalised/displaced position turn out to be the link between the past and the present. Fowles, by positioning the protagonists in such a process, avoids the expectations of the readers about the stereotypical perceptions about the characters. Fowles undercuts the generic expectations of the reader: "Rather than these expected traditional conventions from the novel and the novelist, he pushes the readers to be involved in understanding the process of the writer's showing the different ways of knowing and being ourselves" (9).

6 For Elam, romance as a genre is difficult to define. It means "a narrative which represents a courtly and chivalric age" yet this definition is not sufficient. "Romance is not restricted to medieval tales of brave knights", actually it is a "contradictory term" which documents events "very remote from ordinary life" (Elam 1992: 4-5). Elam asserts that romance is not "merely an alterable set of generic conventions" instead romance always "remarks itself, is always different from itself ... [thus] each text must in some way redefine what it means by 'romance'... Romance makes us uncomfortable because we are never quite sure what romance may mean or how it may mean" (6-7). 7 By depicting familiar historical issues, historical romance could present the past as an imaginary entity. For Gillian Beer, there are some common denominators in historical romances: "Romance invokes the past or the
} 
by getting benefit from the romance as a conventional genre, both reflects the real sexuality of women and male desire (which is suppressed by the Victorians):

... remembering of the past is performed through a re-engendering of the historical past as romance. That is to say, the figure of woman is what allows the past to be represented (via the en-gendering of romance), but she is also the figure whose very inscription reveals, through the play of gender, the impossibility of accurate and complete representation. (Elam 1992: 16)

According to Elam, "romance evokes an unrepresentable other side to history," and romance is regarded as "female fantasy" whose reality is excluded from the mainstream historical/realist novels. Thus, the position of realism and romance in the contemporary era should be taken into consideration:

If realism can only deal with woman by relegating her to romance, if real history belongs to men, and women's history is merely the fantasy of the historical romance, postmodern cultural analysis of history and the 'real' offers a way of revaluing female discourse (Elam 1992: 3).

Today "realism ceases to be the privileged form of representation for the real for historical reality" (Elam 1992:14) and romance deals with the problematic nature of the historical event itself, asking if we can we really know the past by remembering it. If realism means the "accurate representation of the past," romance reveals the artificiality of it and "resists a nostalgic "coming to terms with the past'... [instead it] insists upon the injustice of any such representation, especially that of realism, because [it is not possible] to come to terms with the past, we can never justly represent it" (Elam 1992: 15). This difference between "realism" and "romance" highlights the fact that their aims in re/presenting the past may establish the main aim of neo-Victorian novels as well. This way of treating the past also entails the realisation that it is impossible to reach the real past, fully "coming to terms with it." By being aware of the constructedness of the past neo-Victorian novelists can reconsider the alternate/varied possibilities of the past tied into the present.

In The French Lieutenant's Woman, in addition to the protagonist's being a woman, her existence as a Victorian is also significant. It is indirectly implied that Victorian sexuality will be dealt with throughout the novel. Why sexuality turns out to be the main theme deployed in some neo-Victorian novels when they aim at linking the Victorian and the present is a significant

\footnotetext{
socially remote ... and tends to be set in an idealised world. This distant setting is ... presented with fullness ... The major themes of romance are adventure and sexual love... Well-known stories, reassuring in their familiarity are used and re-used" (Elam in Hughes 1993: 2). In classical historical novels in spite of character's being fictional they "tell us something true about their period because they are representative of it. The aim of such novels is to gain a better understanding, not only of the period chosen, but also of the present as an end result of those remote historical events" (Hughes 1993: 4).
} 
question. The French Lieutenant's Woman is about the tie between Victorian and current sexuality. To a certain extent, Sarah's sexuality is the means of Charles's escape from the restrictions of society. The novel thus deals with the question of individual liberty related with sexual freedom. Foucault writes:

\begin{abstract}
If it was truly necessary to make room for illegitimate sexualities, it was reasoned, let them take their infernal mischief elsewhere: to a place where they could be reintegrated, if not in the circuits of production, at least in those of profit. The brothel and the mental hospital would be those places of tolerance: the prostitute, the client, and the pimp, together with the psychiatrist and the hysteric - those "other Victorians," as Steven Marcus would say - seem to have surreptitiously transferred the pleasures that are unspoken into the order of things that are counted. Words and gestures, quietly authorised, could be exchanged there at the going rate. Only in those places would untrammelled sex have a right to (safely insularised) forms of reality, and only to clandestine, circumscribed, and coded types of discourse. Everywhere else, modern puritanism imposed its triple edict of taboo, nonexistence, and silence (Foucault 1978: 4-5).
\end{abstract}

In a way, neo-Victorian novels aim at depicting the sexually liberated women who are confined by madness, prostitution or poverty. In The French Lieutenant's Woman Sarah's "sexuality" distracts Victorian norms. "Further, the brothel and the asylum" are the places that are organised to enclose Sarah's marginal position (her "shame"). The high society of Lyme Regis regard Sarah's desire to show her shame (not hiding it) means that "she must be mad or a whore" (104-5).

Sarah frequently goes to places existing outside the margins of proper society: the very end of the quay or Ware Commons. Sarah intentionally shows her choice of the margins of society. Hence, Sarah is not appropriate to her time instead she is free of time boundaries. History fails to preserve Sarah since she has a different mind beyond her times. To be an 'other Victorian' in this sense is to be an object of hindrance and desire at the same time. In this respect, through his female character Fowles achieves to transgress the boundaries of time periods by reflecting her from the perspective of 'neo.'

There is an ambiguous attribute of the neo-Victorian novelists about the evaluation of sexuality in these two opposite eras: do they propose a more restricted or liberated kind of sexuality? Are they criticising or praising the Victorian norms of sexuality?

From Fowles through Waters - and with some exceptions like Faber's The Crimson Petal and the White - there has been instead more than a hint of nostalgia for a less sexually knowing and brazenly expressive society ... It is perfectly possible to read The French Lieutenant's Woman as a reaction against, not an advertisement for, the sexual revolution of the 1960s. Its maligned and self-accusing heroine, Sarah Woodruff, assumed to be the French 
Lieutenant's 'whore' by the Lyme Regis population, turns out to be a virgin whose only sexual encounter is with the stuffy, conscience-stricken protagonist, Charles Smithson (Kaplan 2007: 97).

Even when driven by mutual sexual desire, sexuality is a domain where Charles and Sarah feel shame, which shows their suppressed desires as something negative and their innocence as positive.

Neo-Victorianism as a genre somehow "privileges the sex act as a solution or answer" to current concerns of modern people. By this means, it disrupts: "to render visible those sexual and off/scene aspects of mainstream culture" (Marks 2014: 162) which is helpful for neo-Victorianism to benefit from this subverted version of official history. In a way the neo-Victorian depiction of sexuality "thrives upon the binary oppositions and hypocrisies of western culture -- oppositions and hypocrisies neatly encapsulated in a postmodern notion of Victorian" (Marks 2014: 162). Thus neo-Victorian novels have become more explicit.

Through the use of pornographic inclinations within Victorian hypocrisy, neo-Victorian novels show that they are aware of this hypocrisy and the characters in these novels "use innocence as a way to initiate sex" (Marks 2014: 165). As Peter N. Stearns asserts, the stereotypical evaluation of "the repressed Victorian" posits the Victorians as the ones who were "responsible for creating the sex-negative culture that twentieth-century 'moderns' have rebelled against" (47). Yet, as Foucault asserts, the Victorians established discourses allowing sex to become a research subject: "The Victorian period is a key moment in the history of sexuality; the era in which the modern terminologies we use to structure the ways we think and talk about sexuality were invented" (769). Thus, the Victorian era within which sexuality becomes the most buried and highlighted notion that proper human beings refrained from; becomes the time attracting the attention of the contemporary people.

To conclude, The French Lieutenant's Woman with an inspiration from romance including sexuality and through its narrative tactics (including that narrator who manipulates the readers' expectations and perceptions) portrays the possibilities to reach the unseen dimensions of Victorian times. As Sarah and Charles become timeless and universal in their behaviours and choices, their extraordinary love affair struggling to overcome the restrictions of the Victorian times reaches its peak. Especially with the help of the narrator who creates a duplicitous narrative, Fowles presents a neo-Victorian novel by establishing a retrospective view mirroring the blurred existence of the Other Victorians (who are the ancestors of the dilemmas of the modern men). 


\section{References}

Acton, William (1865) Functions and Disorders of the Reproductive Organs. London: John Churchill.

Campbell, James (1975) An Interview with John Fowles. Contemporary Literature 17, 464-65.

Cooper, Pamela (1991) The Fiction of John Fowles. Ottawa: The University of Ottawa Press.

Diniejko, Andrzej (2015) The New Woman Fiction. Victorian Web Organisation. [Accessed: 30 April 2015].

Eddins, Dwight (1976) John Fowles: Existence as Authorship. Contemporary Literature 17, 2-19.

Elam, Diane (1992) Romancing the Postmodern. London \& New York: Routledge.

Foucault, Michel (1978) The History of Sexuality. Translated by Robert Hurley. New York: Pantheon.

Fowles, John (2004) The French Lieutenant's Woman. London: Vintage Books.

Fowles, John (1998) Notes on an Unfinished Novel. In Wormholes: Essays and Occasional Writings. New York: Holt, 13-26.

Holmes, Frederick M. (1997) The Historical Imagination: Postmodernism and the Treatment of the Past in Contemporary British Fiction. Victoria: University of Victoria Press.

Hughes, Helen (1993) The Historical Romance. London: Routledge.

Hutcheon, Linda (1988) A Poetics of Postmodernism: History, Theory, Fiction. London: Routledge.

Hutcheon, Linda (1978) The Real Worlds of Fiction: The French Lieutenant's Woman. English Studies in Canada 4, 84.

Kaplan, Cora (2007) Victoriana: Histories, Fictions, Criticism. Edinburgh: Edinburgh University Press.

King, D. B., Woody, W. D. and Viney, W. (2016) A History of Psychology: Ideas $\mathcal{E}$ Context. $5^{\text {th }}$ edn. NY: Psychology Press. 
Kucich, John and Sadoff, Diane F. (2000) Victorian Afterlife: Postmodern Culture Rewrites the Nineteenth Century. Minnesota: The University of Minnesota Press.

Marcus, Steven (1966) The Other Victorians: A Study of Sexuality and Pornography in Mid-Nineteenth Century England. London: Corgi Books.

Marks, L. H (2014) Behind Closed Doors: Pornographic uses of the Victorian. Sexualities, (17).1: 159-175.

Tarbox, Katherine (1990) The French Lieutenant's Woman and the Evolution of the Narrative. Twentieth Century Literature, (42)1:88-102.

Voigts-Virchow, Eckart (2009) In-yer-Victorian-face: A Subcultural Hermeneutics of Neo-Victorianism. Lit: Literature Interpretation Theory, (20)12: $108-125$. 